\title{
THE BIRDS OF BRITAIN
}

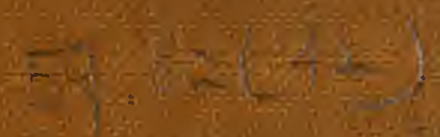




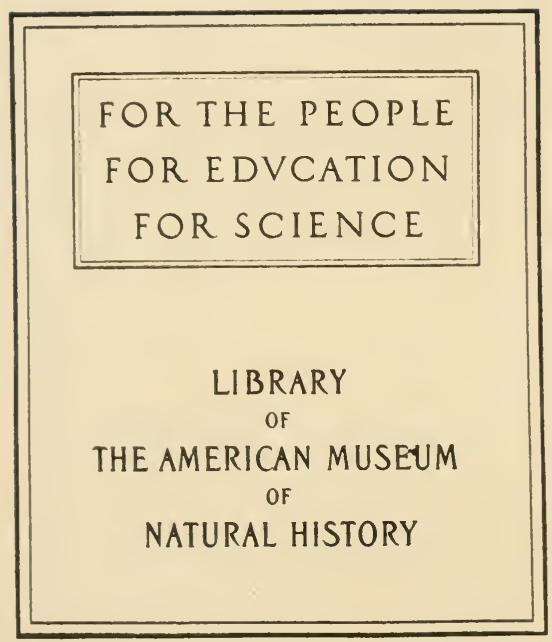




THE BIRDS OF BRITAIN THEIR DISTRIBUTION AND HABITS 
CAMBRIDGE UNIVERSITY PRESS

C. T. Clat, Managier

Ilañan: FETTER LANE, E.C.

EEDinburgh: IO० PRINCES STREET

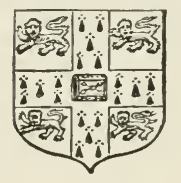

frow Fork: G. P. PUTNAM'S SONS

Gombay, Calcutta and ffadras: MACNILLAN AND Co., LTD.

Toronto: J. M. DENT AND SONS, LTD.

Tokpo: THE MARUZEN-KABUSHIKI-KAISHA

Ail rights reserved 


\section{THE BIRDS OF BRITAIN}

THEIR DISTRIBUTION

AND HABITS

$39 \times 2(42)$

BY

A. H. EVANS, M.A., F.Z.S., M.B.O.U.

ERRATUM

p. 65. In the legend of the picture read 'Pied' for 'Spotted."

Cambridge :

at the University Press

I9I 6 
$\frac{31-120466-\text { ipr. } 16}{0}$ 


\section{PREFACE}

T' $T$ is hoped that this little work, though primarily intended for schools, may be found useful by those who require a short hand-book which includes the results of the most recent observations, and is adapted to modern nomenclature. The author wishes to tender his thanks to Mr W. Eagle Clarke, who is now preparing a new edition of Yarrell's British Birds, for glancing over the proofs, in order that they may be in general agreement with the forthcoming work; while he cannot fail to recall with great regret the times when he was working in company with the late Howard Saunders, then engaged in compiling his well-known Manual of British Birds, or short form of Yarrell.
A. H. E.

9 Harvey Road, Cambridge,

24 February, 1916 



\section{ILLUSTRATIONS}

PAGE

1. Arehæopteryx lithographica. From The c'ambridge Natural History, Vol. Ix

2. A Falcon. To shew the nomenclature of the external parts. From The Cambridge Natural History, Vol. Ix 4

3. The Zoo-Geographical Regions . . . . . 14

4. Ring-ousel . . . . H. W. Richmond . 2I

5. Wheatear . . . . . J. Holmes . . 23

6. Redstart . . . . K. J. A. Daris . 25

7. Robin . . . H. IV. Richmond . 27

8. Nightingale at nest . . . 2 . 28

9. Willow-Wren at nest . . . T. L. Smith . . 32

10. Reed-Warbler's nest . . . J. Holmes . . 35

11. Grasshopper-Warbler at nest . W. Farren . . 37

12. Dipper . . . . . H. W. Richmond . 40

13. Dipper's nest . . . J. Holmes . . 41

14. Bearded Tit at nest . . . W. Farren . . 42

15. Long-tailed Tit . . . . J. Holmes . . 44

16. Long-tailed Tit's nest . . _ , . . 45

17. Coal Tit . . . T. L. Smith . . 47

18. Wren . . . . H. W. Riehmond . 52

19. Wren's nest . . . T. L. Smith . . 53

20. Tree-Creeper . . . . H. W. Richmond . 54

21. Pied Wagtail . . . . J. Holmes . . 56

22. Red-backed Shrikes . . . H. W. Richmond . 61

23. Waxwing in Zoologieal Gardens . , , 64 
24. Spotted Flycatcher

H. W. Richmond .

25. Swallow's nect

26. Sand-martins' burrows 68

27. Bullfinch .

J. Holmes . . 78

28. Corn-Bunting

H. W. Richmond . 81

29. Starling .

J. Holmes 85

30. Jay .

31. Magpie

32. Magpie's nest

33. Raven's nest

34. Rook .

35. Skylark

36. Swift on nest

$$
\text { , }
$$
88

37. Goatsucker and eggs .

38. Woodpecker's nesting-holes .

K. J. A. Davis . 91

39. Green Woodpecker

T. L. Smith .

92

40. Kingfisher .

J. Holmes

41. Hoopoes .

42. Cuckoo ,$\quad$ - $\quad 96$

43. Tawny Owl

H. W. Richmond . 100

44. Griffon Vulture at Zoological Gardens

45. Marsh-Harrier . J. Holmes . . 118

46. Golden Eagle at Zoological Gardens

H. W. Richmond .

122

47. Greenland Falcon at Zoological Gardens .

A. C. V. Gosset . 104

J. Holmes · . 106 ,.$\quad \cdot 107$

H. W. Richmond . 109

J. Holmes · . 110

48. Peregrine Falcon .

49. Merlin's nest and eggs

J. Holmes

126

50. Kestrel

T. L. Smith .

127

51. Cormorants and nests, on Farne Islands

J. Holmes .

H. W. Richmond . 133

52. Gannets nesting on Bass Rock .

53. Common Heron . . . J. Holmes . . 137

54. White Storks at Zoological Gardens H. W. Richmond . 141 
5.5. Spoonbill and Ibises at Zoological Gardens

H. W. Richmond . $1+3$

56. Mute Swan on nest

T. L. Smith . . 145

57. Sheldrake and nest

J. Holmes . . 150

55. Nest and eggs of Teal.

T. L. Smith . . 154

59. Red-breasted Merganser

H. W. Richmond . 162

60. Pock-Dove .

166

61. Hen Capereaillie. . . . . .

62. Red Crouse . . . . .J. Holmes . . 172

63. Pheasant . . . . . . . . 175

64. Red-legged Partridge . . . . . . . 177

65. Water-rail on nest . . . K. J. A. Davis . 180

66. Coot . . . . . J. Holmes . . 182

67. Coot's nest and eggs . . . T. L. Smith . . 183

68. Common Crane at Zoological Gardens . . . . H. W. Richmond . 185

69. Great Bustards at Zoological Gardens . . . . . . . $\quad 186$

70. Stone-Curlew and eggs . . . . 189

71. Ringed Plover on nest . . K. J. A. Davis . 191

72. Lapwing . . . . . J. Holmes . . 194

73. Oyster-cateher . . . . H. W. Richmond . 196

74. Oyster-eatcher's eggs . . . . . . 197

75. Avocets . . . . . . . . . 198

76. Woodeock . . . . . . . 200

77. Common Snipe • . . . J. Holmes . . 202

78. Ruff . . . . . . H. W. Richmond . 209

79. Redshank's nest and eggs . . T. L. Smith . . 213

80. Curlew on nest . . . . R. Ll. Bruce. . 217

81. Common Tern . . . . H. W. Richmond . 224

82. Herring-Gull . . . . " , 228

83. Guillemots and Kittiwakes on the
Farne Islands. , . . 231 
84. Aretie Skua on its eggs . . H. W. Richmond . 234

85. Great Auk, from the Cambrirlge University specimen - 237

86. Guillemots on the "Pinnacles," Farne Islands . . . . H. W. Richmond . 239

87. Black Guillemots. . . . „, . 240

88. Puffins on Farne Islands . . . , , . 242

S9. Red-throated Diver on its eggs . ", . 245

90. Great Crested Grebe on nest - K. J. A. Davis . 247

91. Little Grebe's nest * . . T. L. Smith • • 249

92. Little Grebe's nest with eggs covered . . . . . . . . 249

93. Storm-Petrel . . . . H. W. Richmond . 251

94. Fulmars on eggs . . . . , . 255

These illustrations, of which all but the first three are original, have been reproduced from photographs, taken for the most part from Nature, but in some cases at the Zoologieal Gardens or elsewhere. It is my pleasant duty to offer my thanks to the many kind friends who have assisted in this work, especially Mr H. W. Richmond of King's College, Cambridge, the authorities of the Zoological Society, and those of the Natural History Department of the British Museum. 


\section{IN'TRODUC'TION}

ON THE CLASS AVES, OR BIRDS IN GENERAL

Birds are distinguished from all other living creatures by their covering of feathers. They are moreover bipeds, and have beaks, wings, and tails; but these features are not peculiar to them, while the power of song and the method of reproduction by eggs are also held in common with other animals. Again, ability to $\mathrm{fly}$, in the true sense of the term, is a possession of most species at the present day, but Palæontology teaches us that of old there were flying Lizards, and even now we have flying mammals in the shape of Bats. None of these points therefore, with the exception of the first, are unfailing characteristies of the Class Aves.

There is no doubt that the ancestors of our birds bore a remarkable resemblance to reptiles, and that, if they did not actually spring from them, as is now the orthodox belief, both must have certainly arisen from a common origin, that is, from some creatures combining in themselves those points which the two classes have in common. This is the more evident when we consider the earliest known fossil bird, now termed Archoopteryx lithographica, which was discovered at Solenhofen in the kingdom of Bavaria. It was about the size of a Rook, and was in all probability a tree-loving species. E. B. 


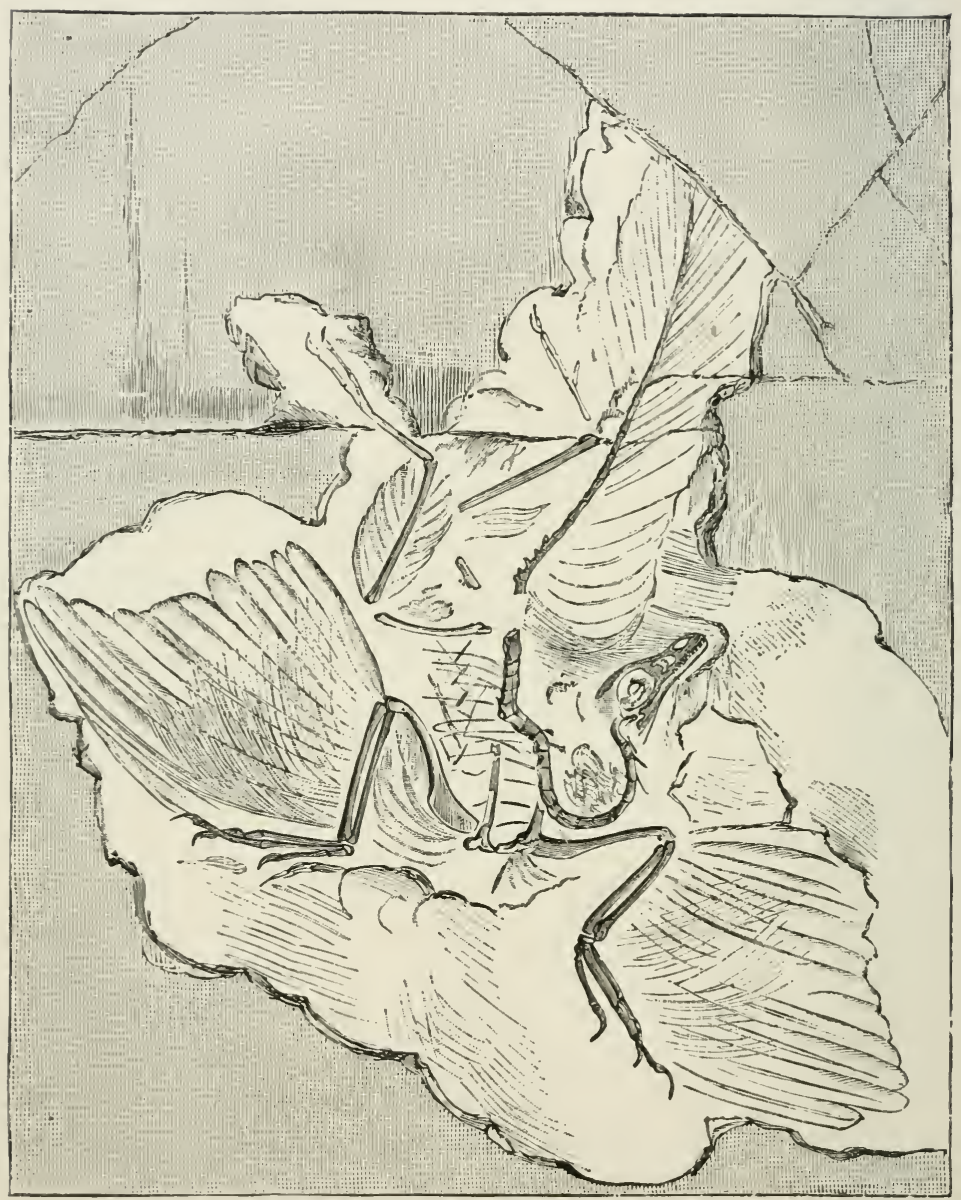

Archæopteryx lithographica 
It had teeth in both jaws of the short blunt beak, a long lizard-like tail with twelve big feathers on each side, wings with both primary and secondary quills, and perhaps a weak keel to the breast-bone. The first two of these points, with other features of the skeleton, distinguish it so sharply from all other birds that it has been placed in a Subelass by itself, termed Archaornithes (ancient birds).

Certain of the latter-day birds have no keel to the breast-bone and therefore no attachment for the flightmuscles-for instance Ostriches, Emus, and Cassowaries; these have been separated from the others and termed Ratitce, as opposed to forms with more or less of a keel, which are known as Carinatce, the latter including all our British speeies, as will be seen below.

We cannot here deal with osteology or anatomy, but the subjoined figure will explain the technical terms used for the feathers on different parts of a bird by seientific writers. They do not grow on all parts of the body alike, but on certain tracts called pterylce, while the unfeathered parts are named apteria. It may be of interest to our readers to learn that the sprouting feather consists of a "barrel" or quill which bears. a tuft of rays called barbs, and that these again by splitting ordinarily produce "barbules." The earliest and softest feathers are those which are collectively called "down," while below each down-feather is formed a contour or webbed feather, so that eventually the latter protrudes with the former at its tip. Subsequently this falls off, as may easily be observed in the young of any down-clad species. Many nestlings, however, have little or no down at all; on the other hand many down-feathers remain continually in their 
original state. In contour-feathers the barbules give rise to "barbicels" which regularly end in little hooks

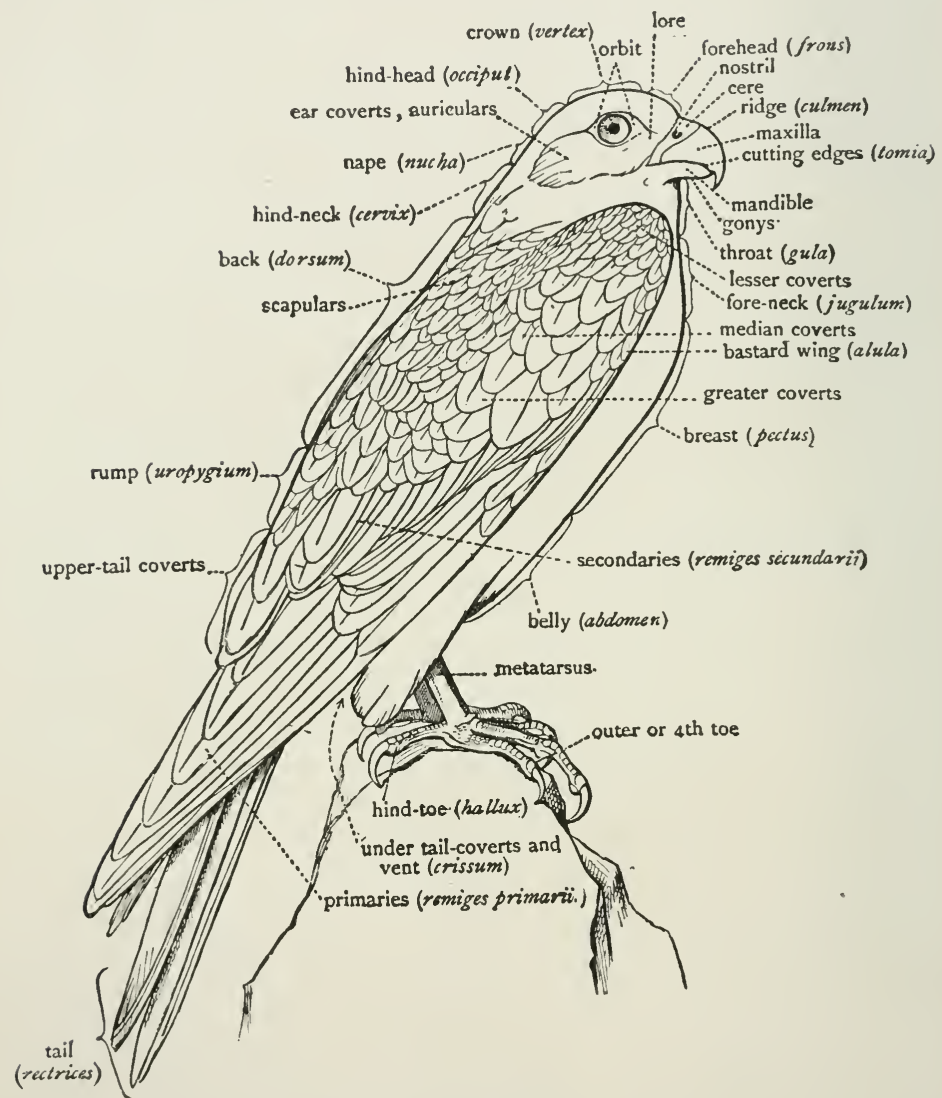

\section{A Falcon}

To shew the nomenclature of the external parts

that catch in the folded margins of the next row and serve to produce a firm surface or "web" on each side 
of the shaft. If barbicels, or even barbules, are absent, the feather is ealled decomposed; if the barbs also are wanting, we have bare quills, wires or bristles.

Birds do not, however, perpetually keep the same coat of feathers, but have periodical "moults," or annual changes. The young do not always lose their main quills in their first year; on the other hand eertain groups of birds not only pass through a regular autumnal moult, but have a second change of the smaller feathers in the following spring. These processes account for the difference between the summer and winter plumages, while some species are known to have three moults, and therefore a distinct summer, autumn, and winter coloration. Decorative plumes are generally assumed in the spring, and are chiefly to be found among the males, which are in the great majority of cases brighter-and larger-than the females. The young are generally similar to the female in colour before they moult.

There are curious exceptions to the above rules, for instance in the Phalaropes and Hemipodes the female is the larger and brighter bird-and there the male takes her place in courtship and incubation; in Penguins the feathers flake off, instead of moulting properly; Gannets take some six years to attain their full adult plumage; most of the Duck tribe lose all their wing-quills at once and then become flightless, while the males temporarily assume the plumage of the females and are said to suffer "eclipse."

The colour of a bird's plumage varies with the seasonal moults, for the most part by new feathers taking the place of the old, but also by the partial or entire wearing away of the edges, whereas ehange of the 
actual colouring matter, if indeed it occurs at all, must be most exceptional. Gloss and iridescence are due to the structure of the feathers, which may be polished or shew little ridges under the microscope.

Newly hatched birds often run from the shell, and are therefore called "nidifugous" or "nest-deserting," but the majority are "nidicolous" or "nest-inhabiting," and fly only when fully fledged; some again of those which run from the shell can only move to short distances for a considerable time. These habits are naturally related to the position of the nest.

With the exceptions already mentioned, and excluding the time of moult, birds have extraordinary powers of flight, though these powers are in constant use only in the case of certain forms, and in others are put forth periodically; speed, endurance, and like factors here come to be considered, while the style of movement, including the amount of wing-action or oarage, and tail-action or steerage power, varies to an enormous extent. The greatest example of untiring flight is that of an Albatros, which will follow a ship for days together; but the same habit, to a less extent, must to most people be familiar in the Gull tribe, which also follow vessels for long periods, and remain on the wing for hours, when looking out for food. These birds are not always flapping their wings, but glide or skim along with intervals of muscular action; while it is evident that they are greatly indebted to the supporting power of the air and its force against the flight-feathers. Vultures, Eagles and Buzzards, Falcons and Hawks have a different kind of flight; they either cleave the air at a great pace or move along slowly but powerfully; and even if they 
soar and circle round in the sky, or hover, as in the case of the Kestrel, their wings are for the most part in a state of constant motion. Many of this family are noted for the swiftness with which they dash upon their prey, so different, for instance, from the soft noiseless progress of an Owl. Storks and Cranes on migration fly for huge distances at great elevations; Swans, Geese, and Ducks, heavy creatures though they are, move at a pace that is readily admitted by the gunner who misses them; Pheasants, Partridges, and Grouse can travel at great rates, and the first-named rise with amazing suddenness from the ground; among the Plovers the Lapwing is noted for its noisy "winnowing" flight, partly due to the wide expanse of its wings; Woodpeckers follow an undulating course, Kingfishers dart from place to place, Larks soar, and almost every group of birds has different methods, of which these are but a few striking examples.

Again, the smallest species traverse incredible distances on migration. This is not perhaps so marvellous in the ease of the Swallow, which careers through the air in untiring fashion at any time, and only alights at intervals, nor in the case of the more powerful Swift, which seems to be able to remain aloft indefinitely, and is rarely seen to perch except at the nest or when roosting; but it is astonishing beyond measure in birds of apparently limited flight, such as Thrushes, Wagtails, Pipits, and dozens of others. Of these the Golden-crested Wren is perhaps the most wonderful, for though the weight to be supported is here inconsiderable, the delicate structure appears to be little fitted to cope with the stormy weather that is often prevalent at the seasons of passage. 
The mechanics of flight are, of course, far beyond our scope, nor will we attempt to account for all the different modes of progression, but we may call attention to the fact that the power of locomotion does not depend on length or strength of wing alone, while the shape of a bird's body, which is often provided with air-sacs, and the more or less hollow bones, are well calculated to make progress in the air as easy as possible.

Consideration of flight naturally leads us to the subject of Migration, which, indeed, we have already been obliged to mention. From ancient times it has been one of the marvels of bird-life, being referred to in the book of Job, by Homer, and the later Greek and Latin poets, as well as by countless subsequent writers. Yet we seem to understand the phenomenon only slightly better than of old, though great efforts have been made of late years to gain more definite knowledge of the magnitude and direction of the movements.

In the first place it is necessary to mention three classes of birds which are often confounded under the name of migrants. The true or summer migrants, as regards Britain, are those which, after breeding in our country, leave it for the winter and return again in spring, the times of their arrival and departure being more or less variable quantities. The partial migrants on the other hand are those which may be said to be more or less resident in Britain as species, though many individuals leave us on migration, and many that have not bred with us visit us at the colder seasons. The birds of passage are those which are only seen for a shorter or longer period in autumn, pass on to more genial 
climates, and are frequently again in evidence for similar periods in spring. The term resident is applied not only to species which never or very exceptionally leave us, but also to those which are for the greater part non-migratory or only share in limited movements within the kingdom. The word "resident" in fact is often used in a comparative sense, and many birds of this description are really partial migrants; this must necessarily be the case as long as we camnot safely assert that the individuals met with in winter are the same as those breeding with us in summer.

Many attempts have been made to ascertain the distances travelled on migration and the direction followed by the flocks, as well as their numbers, the altitude of flight, the pace in the several cases, the most favourable weather, and so forth. Much has been discovered with regard to the four last points by continued observations at Lighthouses and Observatories, coupled with those made on the rate of flight of individual birds; but much less success has attended the constant efforts to determine the two first points. Mr Eagle Clarke in particular has spent an immense amount of time at the seasons of migration at Lighthouses, or on Lightships ; the keepers of the Lighthouses have aided by transmitting specimens that have been killed at the Lights from many quarters, while Mr Clarke has prepared an abstract of such reports; marked rings have been fastened to birds' legs at the nesting places by ornithologists in different countries with a view to ascertaining where they occur at later periods; and finally watcher's have noted the arrival and departure of the different species and filled lengthy lists with their observations. Yet all this good work has but resulted in confirming 
what was already pretty well understood-that is, the great distances traversed by certain birds, and the general direction of their movements. On the other hand a mass of the most valuable information has been accumulated with regard to the methods of migration. Species which ordinarily travel in flocks can be separated from those which are apt to do so singly or in pairs; the numbers in the flocks have been proved often to be incalculable; the altitude has been reckoned in certain cases and found to be so great that it is clear that only the lower flocks are really brought within our ken; bad weather has not proved to be in all cases an obstacle to migration, though the direction of the wind has always to be considered.

Apart from the distances traversed, the direction of migration, that is, the broad lines in which different species travel, is a question of great moment. Birds which breed to the south of the equator certainly tend to migrate northwards; but so little is known of the habits of these southern forms that we must follow the course, usual at present, of confining our remarks to those that breed in the northern hemisphere, while noting that the movements are of much less extent in the southern half of the globe.

On migration the young usually start before the parents, though in exceptional cases, such as that of the Cuckoo, which is reared more often than not by one of our resident species, they linger till a later date. Once started, the direction is distinctly influenced by the conformation of the land; coasts, river-valleys, and so forth making for ease of travel, high mountain ranges for difficulty; but even the last-named are not uncommonly surmounted, and the old idea that straight 
lines were more or less followed has, in the minds of most people, given way to the certainty that the flocks gradually spread over large areas, and that considerable deviations oceur, for which at present it seems impossible to account. Many birds, such as our Swallows, are seen to collect together some time before they leave us, others, such as Woodcocks, arrive simultaneously in large flocks, while close observation soon shews that a very great number of other species act similarly, and that " rushes" continually oceur, which are most strikingly witnessed at Lighthouses. Migration, however, takes place largely at night.

The causes of migration have been a fruitful source of discussion, but there is a general agreement that changes of temperature and the available food-supply are the most effective. Exceptionally hardy birds, such as Penguins in the southern oceans and the Spitsbergen Ptarmigan in the north, especially if they live on the sea or in districts thinly populated by their kind, need hardly migrate at all; but, as regards the more delicate forms, the colder weather that begins in autumn might of itself be sufficient to drive the birds from their breeding quarters. This colder weather also diminishes the supply of inseet food, while the season of berries and other fruits soon comes to an end, and even the smaller mammals on which some birds feed almost cease to be seen. It does not follow that northern species stand in need of very high temperatures during the winter; if so, they would probably stay in great numbers near the equator, instead of so constantly passing further to the south, and, as already stated, the more adaptable species, specialized to that effect, may remain throughout the year in Arctic or 
Antarctic climates. All birds that fly are capable of migration to a greater or less extent, but all do not take full advantage of their capabilities.

The return migration in spring to the northerly breeding haunts may be due to some hereditary instinct -whatever that expression may mean-or to the fact that the birds seek what they know to be the places most favourable for rearing their young in the particular manner to which they are accustomed, or even to the pressure of the species of the southern hemisphere which may be returning from their winter quarters, though this argument does not seem very convincing.

It has also been suggested that migration may be due to the same cause as an extension of breeding range; that is, the numbers may become too great to be contained in the original summer haunts, and under pressure a certain proportion may move further to the south, when they cannot well go further northward. But, since it can hardly be contended that there is absolutely no room left in most areas for the birds' nests, and since so many of them breed in colonies and do not at present dispute the possession of every inch of soil, this argument practically resolves itself into that concerned with scarcity of food.

Finally it may be observed that the length of the journeys taken by various species of birds differs immensely; many move to comparatively short distances, while such forms as the Turnstone and the Sanderling, which breed in the far north, go so far south in winter that they may practically be considered cosmopolitan.

Migration naturally leads to thoughts of geographical distribution, and care must be taken not to confound 
the two questions. By distribution we mean, unless it is otherwise stated, the limits within which a species ranges in the breeding season, just as the bird's range is, if unqualified, taken to mean its summer range. Even in Britain distribution is often limited, as in the case of the Snow Bunting of the Scottish highlands or the Nightingale of England; but the range of each species will be found given in detail below, and need not delay us here. Many birds throughout the world are extremely local; many are only found in deserts, isolated islands, and so forth, while the Red Grouse may be given as the example nearest to our doors, as it is absolutely confined, as a native species, to the United Kingdom. But Britain is a comparatively small area, and it is necessary to survey the whole globe in distributional questions. This is far beyond our scope, and we need only state that, taking into consideration birds alone, Dr P. L. Sclater suggested a division of the world into six Regions, the Palæarctic, Ethiopian, Indian, Australian, Nearctic, and Neotropical (see map), in each of which he considered the forms-taken as a wholeto be more closely connected with each other than with those of another Region. The Palæarctic and Nearctic (of the Old and the New Worlds) together form the Holarctic; New Zealand may be considered separately.

If our readers ever proceed from the study of British Birds to that of foreign species, they will be greatly struck by the prevalence of very peculiar forms in certain countries, by the wonders of the Arctic and Antarctic areas, by the marvels of desert and island life, by curious extinct birds, by extraordinary habits of courtship, sexual display, parasitism, and many other subjects, but even within our islands they may spend 
a pleasant and useful lifetime in observing the species they meet with, in protecting them and carefully noting their habits, which will often be found to be much more peculiar than is usually supposed to be the case. Their cleverness is not uncommonly remarkable, and their structure admirably adapted to the needs of their

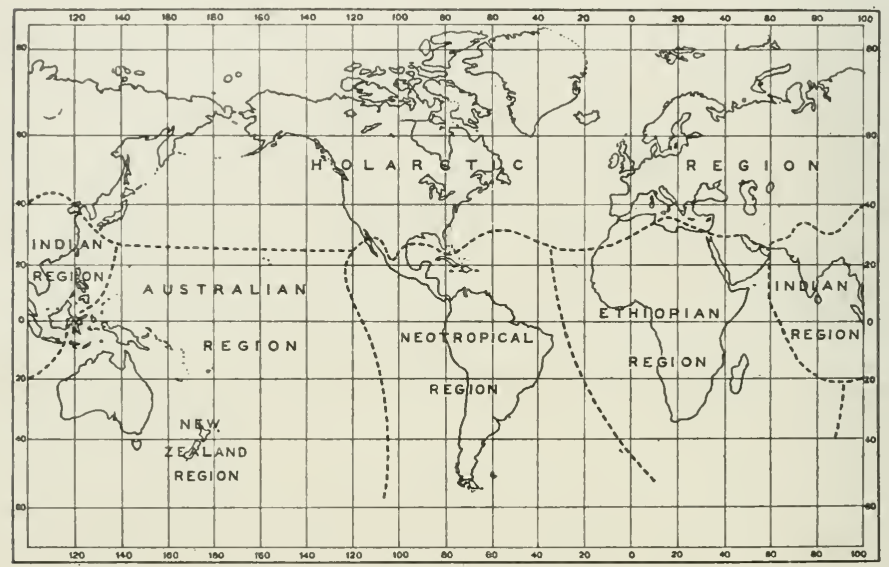

The Zoo-Geographical Regions

existence, while the changes of plumage are of themselves a lifelong study and are none too well understood even at the present day, especially with regard to the young bird. No doubt all the species on our list cannot be found in any one locality, but there is no district where much good work may not be done. 


\section{CLASSIFICATION}

Birds may roughly be classed as land birds and water birds, but there are many that can hardly be included properly in either category; it is still less possible to divide them by their dwelling-places, as those of the woods, fields, shore, and so forth; we require some formal elassification into "Families" under the larger groups called "Orders," though it is clear that no linear arrangement can be entirely satisfactory, or will shew all the relations between the members of the "class" Aves. We will therefore give here the scheme used in the following pages, which is almost the same as that in Howard Saunders' Manual of British Birds. The nomenclature is almost exactly that of the new List of the British Ornithologists' Union.

\section{AVES CARINATA}

\section{ORDER I. PASSERES}

Family Turdide

Subfamily Turdince

Subfamily Sylviince

Subfamily Accentorince

Family CINCLID

Family PandRID E

Family PARIDE

Family REGULIDE

Family Sittide

Family Troglodytid A

Family CerThIDde

Family Motacillide
Family ORIOLIDæ

Family Lanidoe

Family AMPELID E

Family Muscicapide

Family HirdndinId e

Family Fringinlide Subfamily Fringillina Subfamily Emberizino

Family Sturnide

Family Corvide

Family Alaudide 
ORDER II. PICARIAF

Family Cypseutde

Family CAPRIMULGIDE

Eamily PICIDE

Subfamily Iyngince

Subfamily Picince
Family ALCEdinide Family Coracinde Family UPUPID Family Cucourde

ORDER III. STRIGES

Family Strigid 2

ORDER IV. ACCIPITRES

Family Vulturid

Family FaLCONIDE

ORDER V. STEGANOPODES

Family Pelecanide

ORDER VI. HERODIONES

Family Ardeide

Family CiconIIDæ

Family IBIDID

Family Plataleidex

ORDER VII. ODONTOGLOSS

Family Phenicopterid ex

ORDER VIII. ANSERES

Family Anatides

Subfamily Anserince

Subfamily Cygnince

Subfamily Anatince

Subfamily Fuligulince

Subfamily Mergince

ORDER IX. COLUMB开

Family Coldurides

ORDER X. PTEROCLETES

Family Pterochide 


\section{ORDER XI. GALLINA}

Family Tetraonide

Family Prasianid

ORDER XII. GRALLA

Suborder Fulicariæ

Suborder Otides

Family RaLlid

Suborder Grues

Family OTIDIDE

Family Gruide

\section{ORDER XIII. LIMICOLA}

Family EDICNEMID

Family Glareolide

Family Charadridde

\section{ORDER XIV. GAVIAE}

Family LARID

Subfamily Sternince

Subfamily Larince

Family Stercoraridee

\section{ORDER XV. ALC平}

Family Alcid 2

Subfamily Alcince

Subfamily Fraterculince

\section{ORDER XVI. PYGOPODES}

Family Colymbide

Family PodictPedid

\section{ORDER XVII. TUBINARES}

Family Procellaridde

Family Puffinides

Family Dromedeide

E. B. 


\section{ORDER I. PASSERES}

This Order includes all the true singing birds, in which the vocal organs are most highly developed; moreover in every respect they certainly represent the highest stage of development in the Class. The members are of all sizes and colours, and for the most part haunt trees or bushes, so that they have been somewhat arbitrarily called perching birds, though perching is not a habit peculiar to them. The toes are all on the same level and never webbed; the young are born naked and helpless; but these characteristics will not alone determine the Order, which contains about half of the birds that are at present known.

It may be well to mention three important points before going further, to prevent future confusion. First, the descriptions of the Orders must be taken to refer to British forms alone; second, the range of a bird is used in the sense of its breeding range; third, what is commonly termed a bird's leg is mainly its foot, the real leg being often hidden by the plumage. The word foot is hereafter used in its correct sense.

\section{Family TURDID $Æ$, or Thrushes, Warblers, and their Allies}

Subfamily Turdinæ, or Thrushes, Chats, Redstarts, Bluethroats, Robins, and Nightingales

This Subfamily is very closely allied to that of the Warblers (Sylviince), but differs in the more or less spotted condition of the young, above and below, until their autumn moult; of this the Robin is a good instance. 
Three typical Thrushes are residents or partial migrants in Britain. Of these the Mistle, i.e. Mistletoethrush (Turdus viscivorus), is the largest, and is especially noticeable in early spring, when its loud churring notes, coupled with a harsher song than that of the Common Thrush, may be heard in the roughest weather. Hence it is known as the Stormcock, while it is often called a Feltyfare in mistake for the Fieldfare. In plumage it is greyer than the common thrush, with white instead of orange-buff under-wing; in flight it is swifter; in food it shews a greater liking for fruit and berries, including those of the mistletoe. The young have much white on the wing-coverts. The Mistle-thrush is a bird of the hedgerow and copse, not of thick woods, and has spread to the northern islands of Scotland and to Ireland during the last century or so, with the increase of plantations. The nest, a solid structure of grass and moss, lined with finer materials, is seldom placed near the ground, but occupies some conspicuous fork of a branch; the four or five greenish or reddish white eggs are finely marked with rusty red and lilac. This species is an early breeder, but is certainly to a large extent migratory; it is a shy bird, though bold at the nest. It occurs throughout most of the Palæarctic region, but not within the Aretic circle.

The Common or Song-thrush (T. musicus clarkii) is too familiar to need description either as regards its plumage or its varied song. Its foreign range is not very dissimilar to that of the last species, but the continental form is distinguishable from the British in coloration, and we are thus able to gain a rough idea of the number of individuals that arrive from abroad in autumn or leave us for the winter, though some are undoubtedīy 
resident. With us it ranges even to Shetland, and occurs fairly high on the hills, the well-known mudlined nest being occasionally placed on the ground, but generally in trees and shrubs. It lays from four to six blue eggs with black or brownish spots. Except during the moult the song may be heard at any season, while the bird has its first brood exceptionally early in the year. The food consists of berries and insects, worms, slugs, and snails, especially the last, which are usually smashed on some favourite stone.

The Blackbird ( $T$. merula) is so called from the cock, which is black with orange bill, while everyone knows that the hen and young are dull brown with the bill dusky. When feeding on the ground this species has not quite the "hop and run" action of the thrush, but its food is the same and its flight similar. It is, however, a bird of lower levels, constantly flushed from hedyerows or bushes, and less often sitting on tree-tops to sing. The song is comparatively flute-like and mellow. The nest of dry grass and mud, with grass lining, contains about five green eggs with small rufous markings, and is placed at no great height from the ground or even on it. Common throughout Britain and a partial migrant, the Blackbird is not found outside Europe, except in Asia Minor, Palestine, and north-west Africa, with the Atlantic islands.

In the hilly moorlands from Cornwall and Wales to northern England and Scotland it is represented by the Ring-ousel or Hill-blackbird ( $T$. torquatus), characterized by the white chest, less conspicuous in the female and still less in the young, and also by the yellowish bill with black tip. This migratory species arrives about April and leaves us by October, with the exception 
of belated individuals, while it only breeds in northern Europe, the central and southern European form being distinguishable. Its ringing note or whistle is a characteristic sound of our higher hill-slopes, but the performer is less often seen than heard, for it is a shy bird except at the nest. This is like that of the Blackbird, but is placed among rocks, in heather, or

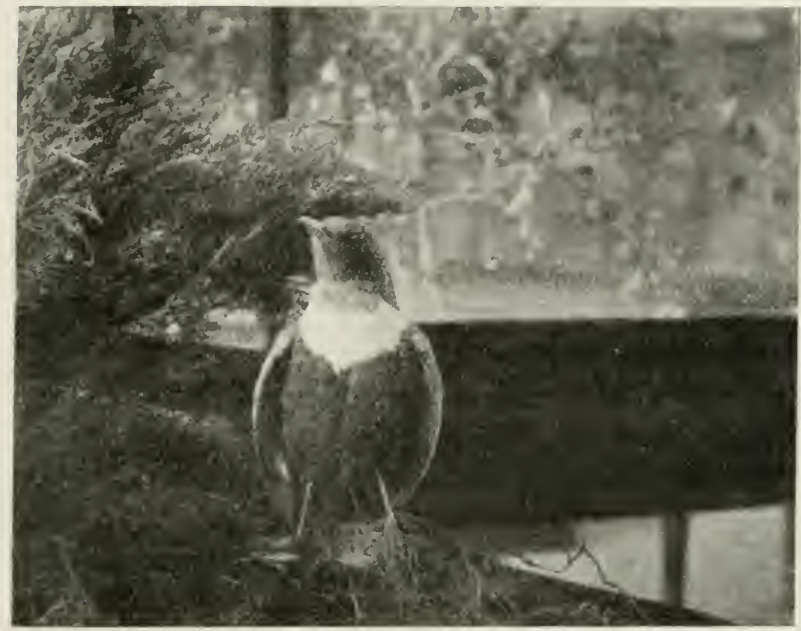

\section{Ring-ousel}

on banks of streamlets; the eggs are brighter both in the ground-colour and the larger spots. Berries form a considerable part of the food, especially on passage, which the birds compass easily.

We now come to two migratory species, common with us in winter, the Redwing and the Fieldfare, which somewhat resemble a small Song-thrush and Mistlethrush respectively. The Redwing ( $T$. iliacus) may, 
however, be distinguished by the red, in place of orangebuff, below the wing and the broad whitish stripe above the eye; the Fieldfare ( $T$. pilaris) by the distinctly grey head and rump and the yellower breast. They both breed in northern Europe and in Asia eastward to the Lena river, but the former alone nests in Iceland and the Færoes, while the latter ranges further south to central Germany and Austria-Hungary, and often forms colonies. The nests and eggs are much like those of the Blackbird. These Thrushes come in large flocks in October or earlier, and leave about April; the Fieldfares keeping more together and being easily recognisable by their harsh chattering cries as they fly about the fields and hedgerows, whereas the Redwings separate and have a more melodious call. They are shy birds of swift flight, often shot for the table in winter, and not uncommonly killed by severe cold, the Redwing being the first to succumb to the effect of the weather.

Very different in appearance from the true Thrushes are the Chats, Redstarts and Bluethroats, the Redbreast and the Nightingale; nevertheless they are the connecting links with the Warblers, which are usually on anatomical and other grounds included in the Family Turdidne as a Subfamily Sylviinoe. The habits vary, but the food seems always, if we leave the Robin out of consideration, to consist of insects and their larvæ, spiders, worms, and small mollusks. The Chats are conspicuous and lively birds, with jerky flight, pleasant little songs, and sharp clinking call-notes that explain their name, the largest being the Wheatear, i.e. whiterump (Enanthe onanthe), which is locally abundant on moorlands, downs, and sandy warrens. It is one of our 
earliest spring migrants, arriving in mid-March, and making pretty straight for its breeding quarters, while it leaves the country by October. But it is not till April or May that it builds its nest of grass lined with fur, hair, or feathers, which is placed in a rabbit-burrow or similar excavation in most cases, though it may be

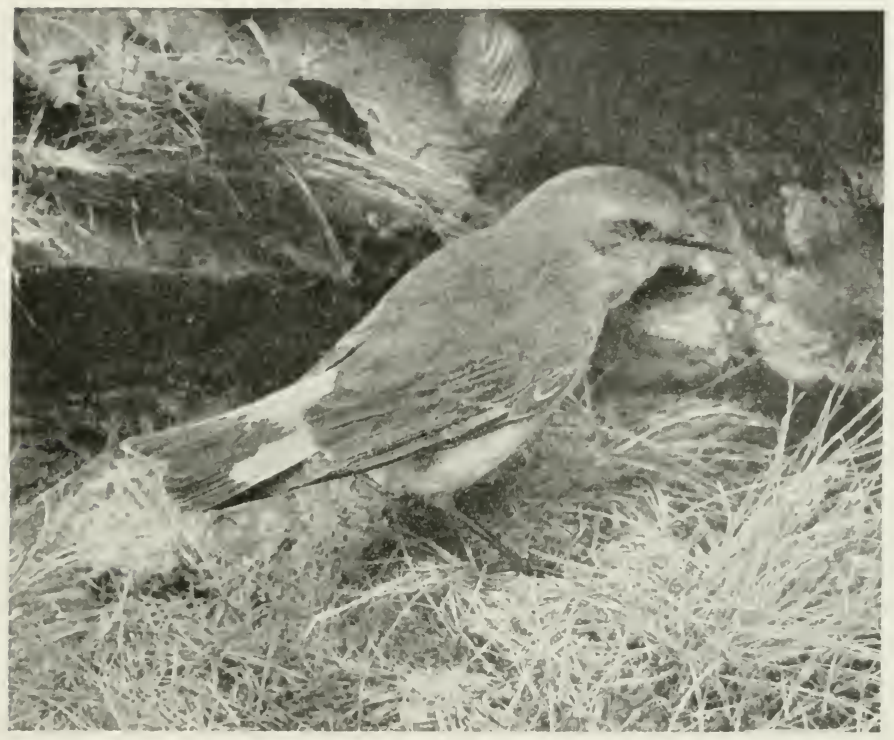

\section{Wheatear}

in holes in walls or peat-stacks on the moors, while a little building material at the entrance generally betrays the site. The five or six eggs are very pale blue, rarely with a few purplish specks. The Wheatear, from its similar note, is often confomded with the Stonechat, but may readily be distinguished by its grey back, black cheeks, wings, and tail, white rump and breast. 
The female is browner and buff below. The range extends over the whole Palæarctic region from Jan Mayen and Mongolia southwards and even to the Azores, but a larger race inhabits north-east America and Greenland and visits Britain on migration.

The Whinchat (Saxicola rubetra) is found in rough grassy places of various descriptions, with a preference for moors and newly planted copses ; it is mottled with brown and buff above and is fawn-coloured below, having over the eye a distinct white streak-which is buff in the female-and some white on the wing and tail. The nest, usually placed near the base of a small shrub or large herbaceous plant, is a mossy structure with a lining of fine grass, and contains about six green-blue eggs, generally with rufous spotting. The hen-bird sits very closely, while when disturbed both parents flit before the intruder, perching on the shrubs, and repeatedly uttering their alarm note of " $u$-tick." Breeding takes place about mid-May, but the bird arrives a month earlier and stays till October. Abroad it ranges through Europe to west Siberia, though it keeps to the hill country in the south.

The Stonechat (S. rubicola) should really be called the Whinchat or Furzechat, as it is most common among furze, where it may be seen throughout the year, though as a species it is partly migratory. The cock, a brown bird with black head, a ruddy breast, a white patch on the wing and a partial white collar, is very conspicuous as it flits in a fussy way from one perch to another, uttering its clicking notes as a warning to the hen, which is almost brown. The nest is placed among heather, rough grass, or very low gorse, and is made of moss, grass and so forth, with a finer lining; 
the five or six eggs are greenish with rufous spots, usually placed in a ring. They may be found from early April to August, so doubtless two broods are reared in a season. The nest is well concealed and the hen sits elosely. Our bird is confined to Europe and north Africa, but has several near relatives.

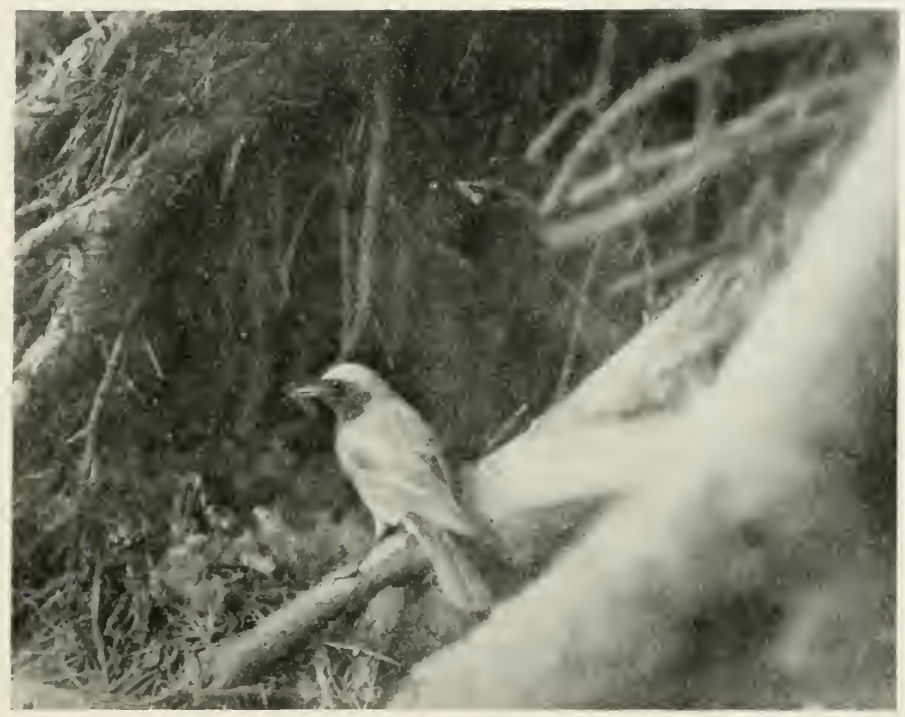

Redstart

The Redstart or Fire-tail (Phonicurus phonicurus) is well known throughout England and Scotland from April to September, but is rare in Ireland and hardly reaches our northern isles. It is by no means shy and often very bold at the nest, while a bird of active ways with grey back, white forehead, black face and throat, chestnut breast, and orange-red rump and tail, which 
it is always flirting, is not easily overlooked, even in the wooded country which it chiefly haunts. Its sweet low warble is perhaps most commonly heard in the valleys of our northern hills; the nest of moss, grass, and roots, lined with hair and feathers, is generally built in a hole in a rotten tree or wall, and contains some six pale blue eggs. The bird has a wide foreign range from northern Norway to Lake Baikal, and southward throughout Europe to the Atlas mountains in north Africa, but complications arise from the existence of several closely allied forms. The hen has a plain head and brownish back.

The Black Redstart ( $P$. titys), as its name implies, is black with a red tail, the upper surface being somewhat greyer with a white wing-patch and the two central tail feathers brown, as they are in the Common Redstart. To travellers in Germany it is a well-known bird, for it builds its nest round houses and sheds, while it is specially interesting to us as having been suspected of breeding in England and being a frequent autumn visitor. The female resembles that of the last species but is greyer; the male has a richer song; the eggs are white. The range extends from the Baltic and the Urals to Rumania, Palestine, and north Africa.

The Red-spotted Bluethroat (Cyanosylvia suecica) is an irregular autumn and rare spring migrant, which deserves special notice as linking the Redstarts to the Robin and the Nightingale, and so to the Warblers. It has the general habits and nest of the Robin, while the song is little inferior to that of the Nightingale, and the eggs are similar. The male is brown, with white eyestripe, rufous rump, and blue throat; the throat has a red central spot and is bounded by black, followed by 
a rufous patch above the white belly: the female has little blue on the throat and a brown chest-band. This species only breeds in the north of Europe and Asia, but there is a form with a white instead of a red spot which carries on the range to France and west Russia.

Our familiar Robin or Redbreast (Erithacus rubecula melophilus) needs no deseription; its plumage, habits,

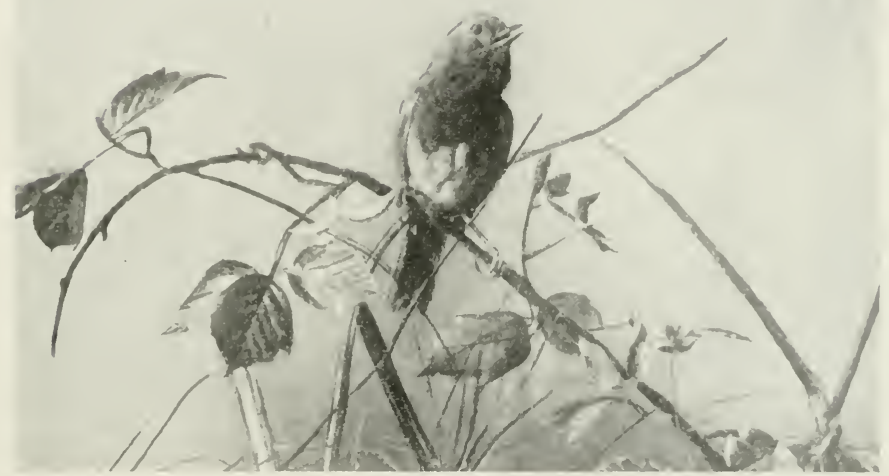

Robin

and song are equally well known. It may be mentioned, however, that it is not known to breed in the Færoes or Shetlands, though it ranges from north Europe and west Asia to Africa and the Atlantic islands, while the continental race is clearly distinguishable and visits us in winter and the African form has also been separated. Holes in banks, walls and trees are utilized for the nest of leaves and moss lined with hair, while the 
bird has a great fancy for an old can or box, as occasionally happens with the Wheatear and Stonechat. The first brood may be hatched early in April: the eggs are white with rufous spots.

The Nightingale (Luscinia megarhyncha) is no doubt our most wonderful songster, though it is approached by the Thrush and nearly equalled by the Blackeap and

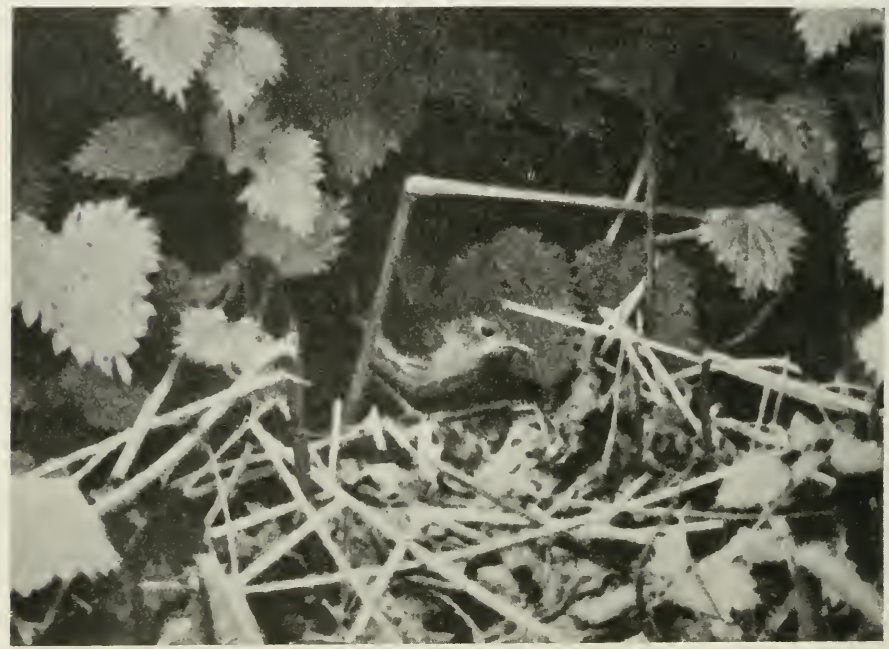

\section{Nightingale}

the Garden Warbler. Its song, however, gives way to a harsh churr when the young are hatched, as in the case of so many Warblers. Arriving in April it soon becomes common in eastern England, though less abundant westward, and barely known in Devon, Hereford and Cheshire. Exceptionally it has been found breeding in Glamorgan and north Yorkshire, as well as on one occasion in Northumberland. Though 
the Nightingale remains with us till September, it is little seen after the breeding season, and even then chiefly as a reddish brown bird which pops out in front of the observer and flies along to a neighbouring hedge or bush. The curious nest is made outside of dry leaves, usually of the oak, and is placed in vegetation on the ground, or close to it; the five or six eggs are olive eoloured or greenish with olive-brown markings. The range extends from central Europe to Asia Minor and north Africa.

\section{Subfamily Sylviinæ, or Warblers}

In treating of the Warblers, the first point to notice is that all students of bird-life must learn their notes in the field. We cannot pretend to reproduce them here, and the syllables given to represent them in books are rarely understood alike by any two persons. This is, moreover, true of most bird-voices; we may truthfully talk of a croak, a click, a hoot, a warble, and so forth, or speak of such as harsh or sweet, but attempts to imitate them on paper are sure to mislead. Warblers live on slugs, worms, spiders, insects-aquatic or otherwise-and their larvæ, according to the species, and some on fruits also; insects are often captured on the wing, while the smaller members of the group flit characteristically among the leaves of trees, hunting for their prey.

With this prelude we may proceed to the Common Whitethroat (Sylvia communis), the familiar species of our more open woods and roadsides, easily recognised by its early arrival, its habit of springing up a few feet in the air to utter its monotonous notes before settling again on the hedgerow, its white throat and its ruddy brown 
colour above. The more shy Lesser Whitethroat ( $S$. curruca) has a white instead of a buff breast and a very much finer song of a somewhat similar character; it is always a more local bird, not nesting in Ireland, very seldom north of the Border and sparsely in Wales, while the commoner species is universal south of Sutherland and Caithness. Similarly, outside of Britain, the range of both covers Europe south of lat. $65^{\circ} \mathrm{N}$. and southwest Asia, though in some parts the smaller bird is the more abundant. Moreover it extends to Siberia, while its congener breeds in Algeria and Tunisia; but all depends on the number of forms we recognise; as several are closely allied. The flimsy nest of grassstems and cleavers is placed in low bushes, brambles and hedges; but the Common Whitethroat is fond of nettles and coarse herbage to conceal its nursery, while that of the Lesser is more often in young hawthorns, blackthorns, and similar situations, and seems absurdly small in comparison. Its five or six eggs, moreover, have a clearer white ground than those of its congener, with olive and brown rather than green markings, and resemble those of the larger Garden Warbler.

The Blackcap Warbler (S. atricapilla) and the Garden Warbler (S. simplex) are in song worthy rivals of the Nightingale, which some may even consider inferior, though it certainly has more variety of phrases. But, while the songs of the two species may be easily mistaken, the male Blackcap with its black crown, grey nape and under parts can never be taken for the olive-brown Garden Warbler with its whitish lower surface. The female, which has a red-brown instead of a black head, is particularly hard to identify in a dark thicket; yet this is often necessary, as the nests are similar and the 
whitish eggs with yellowish brown spots may correspond exactly. It is generally possible to make a correct guess at the nest, which in the Garden Warbler is less flimsy and better lined with hair, but the very green variety of its eggs and the rare red variety of those of the Blackcap can alone be guaranteed without a sight of the parent. All the Warblers so far mentioned arrive about April and leave us in September, but the Common Whitethroat is the earliest and the Garden Warbler the latest. The Blackcap and Garden Warblers both range in Britain up to mid-Scotland, and the former a little further north; they vary in abundance locally, but agree in being scarce in Ireland. They breed over Europe, except the more Arctic portions, and in northwest Africa, but the eastern limits in Asia seem to lie in western Siberia, and only the Blackcap nests in the Atlantic islands.

The Dartford Warbler (Melizophilus undatus) is a jolly little dark grey bird with chestnut breast, which is usually seen flitting restlessly about the gorse bushes or tall heather; it is now scarcer with us than formerly, and is confined to East Anglia, Shropshire, and the south of England. Abroad it occurs in north-west France and in barely separable forms to Italy, Morocco, and Algeria. Though skulking at other times this local resident is often bold enough in the breeding season, when the cock utters his scolding notes from a spray just ahead of the intruder, and shifts his quarters but slightly when disturbed. The nest and eggs much resemble those of the Whitethroat, but the latter are somewhat longer with more olive or even reddish markings. The site of the nest is in a gorse bush or heather clump, while in winter the birds move from place 
to place for shelter, as they are the reverse of hardy. The foreign range is complieated by the presence in the Mediterranean of the more uniformly grey Marmora's Warbler.

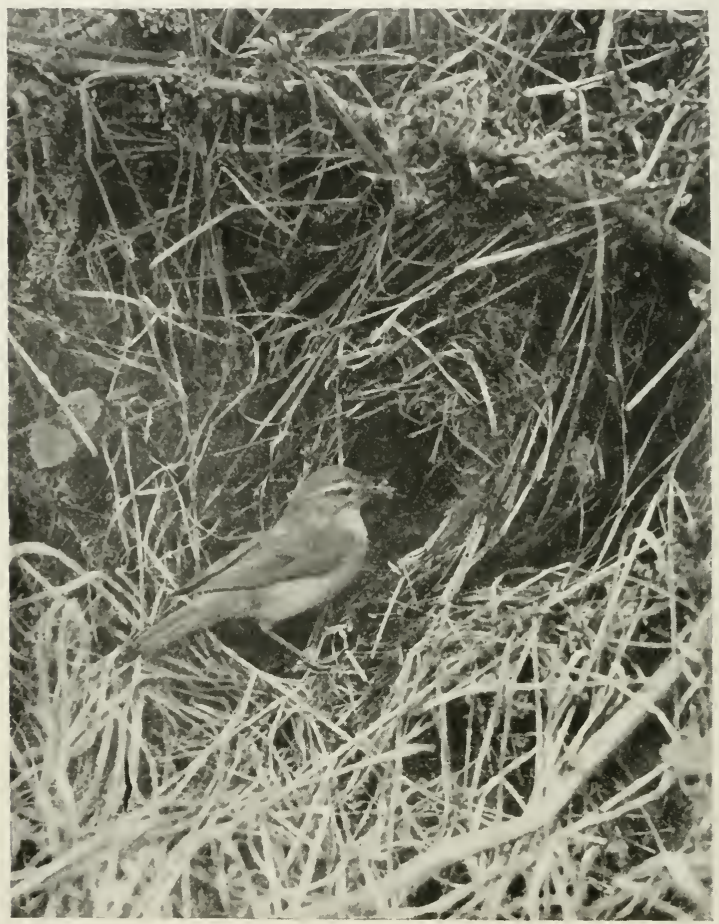

\section{Willow Wren}

The Willow Warbler or Willow "Wren" (Phylloscopus trochilus) is the commonest of three little yellowish Warblers which appear very early in spring and leave under ordinary circumstances in September. It is no 
less abundant in the north than in the south and in Ireland, and even breeds in Shetland, while abroad the typical form ranges from Lapland and north Russia to the Mediterranean, except for the Balkan Peninsula.

The Chiffchaft ( $P$. collybita), a more local bird, which barely extends to northern scotland, is only found in its typical form from France and Germany southward in Europe and is replaced east of the Volga by the Siberian Chiffchaff, known also to breed in north Russia. The Scandinavian Chiffchaff oceupies north and east Europe, and a smaller form is found in the Canaries. The Wood Wren ( $P$. sibilatrix) is the rarest of our three species, and prefers oak woods and hill-valleys; it is a somewhat less northern bird than the Willow Wren, but reaches the Mediterranean. All three are yellowish green above and lighter below, with a yellow streak over the eye, but the distinctly yellow breast of the Wood Wren clearly distinguishes it from the other two, in which the breast is yellowish white. The Chiffchaff is duller and smaller than the Willow Wren with darker feet. But, apart from plumage, they are easily recognisable by their notes and breeding habits. The song of the Willow IVren consists of a few sweet reiterated notes, occasionally swelling into a song like that of the Garden Warbler; the Wood Wren, after a similar start, ends with a long drawn trill; the Chiffehaff says "chiff-chaff" most distinctly. The song is usually accompanied by a quivering of the wings: the hens merely utter a plaintive sound. The nests are oval balls of grass with a side entrance; but those of the Willow Wren and Wood Wren are very seldom placed above the ground, while that of the Chiffchaff is nearly always in a low bramble, small shrub, fern or grass-tuft; the Wpod Wren lacks the 
usual feather lining and has five or six eggs thickly spotted with purplish black, the spots in the Chiffchaff being also purplish though sparse, and in the Willow Wren red. The last-named does not coat its nest with dry leaves, as the others constantly do. These three birds are regularly seen foraging over the green leaves on the higher branches of trees for flies, aphides, and the like, a habit which has given them the name of Phylloscopus or "leaf-investigator" ; the Chiffchaff is the earliest to arrive, the Wood Wren the latest.

We now come to another small group of three migratory Warblers, which visit us between the latter part of April and September; their general coloration is reddish brown with buffish white under parts, and they have a conspicuously rounded tail. Careful attention is necessary on the part of a beginner to distinguish them by their hurried babbling notes, apart from difficulties with regard to the plumage. All are aquatic, but the Reed Warbler (Acrocephalus streperus) is seldom found except in beds of reeds (Phragmitis vulgaris) and does not range north of Yorkshire, or to Ireland: abroad it occurs from south Sweden and south-western Siberia down to the Mediterranean, north-west Africa, and Baluchistan. The Marsh Warbler (A. palustris) has a slightly more southern foreign range, and is at present only recorded as breeding with us in Somerset, Gloucester, Worcester, Oxford, Wilts, Hants, Sussex, Kent, Surrey, Bucks, Cambs, and Norfolk; it usually haunts osier holts and damp copses, and eschews reedbeds. The Sedge Warbler (A. schœnobonus) breeds throughout Britain in suitable places, but always near water, though a small ditch may suffice, whereas the last-named species has been known to nest in cornfields. 
Abroad the Sedge Warbler extends throughout Europe from $68^{\circ}-70^{\circ} \mathrm{N}$. lat. to the Mediterranean, and westward in Asia to north Siberia and the Altai mountains.

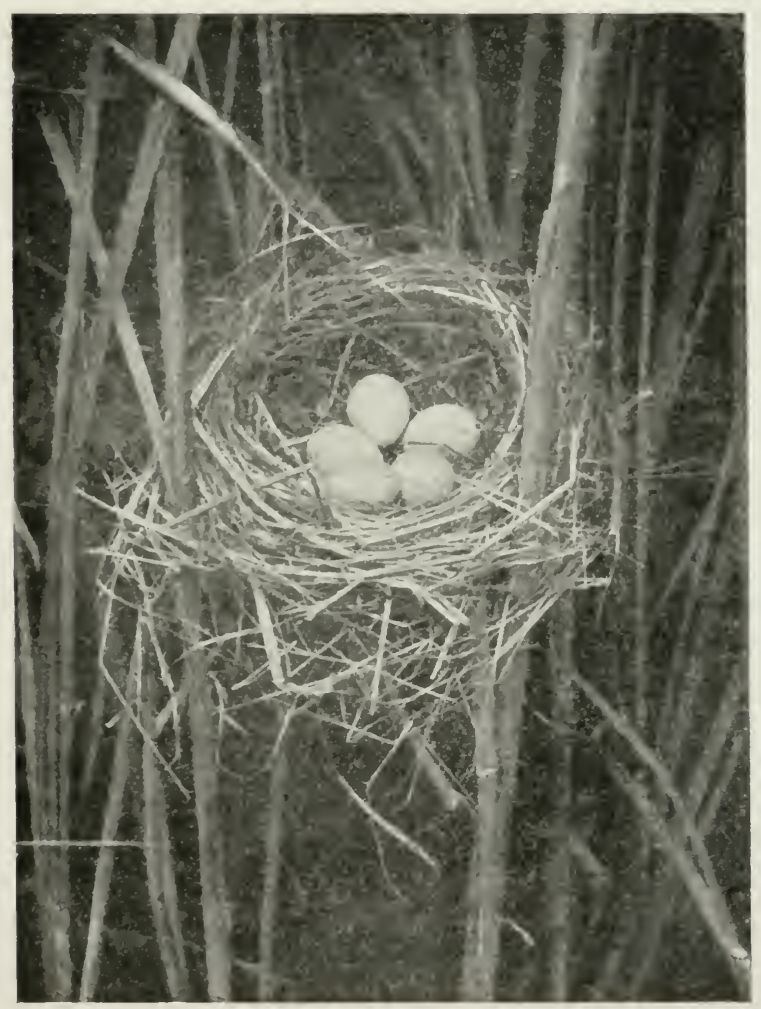

Reed Warbler's nest

Experts themselves often fail to distinguish skins of the Reed and Marsh Warblers, but the latter is more olive above and has brownish flesh-coloured in place of 
purplish brown legs. Both these birds are nearly white below and have an obscure buff streak over the eye : the Sedge Warbler on the contrary has a buff breast, a distinct yellowish white eye-streak, and a streaked instead of a plain crown. The respective haunts and habits are, however, characteristic, while the birds, though in constant motion except when singing, can scarcely be called shy and are easily observed. When not built in herbaceous plants or bushes, the Reed Warbler's nest is slung between three or four reeds standing in water, and is an elongated structure with a deep cup, lined with wool or hair, to contain the four or five greenish white eggs with olive and grey blotching; it almost dwindles to a point below, and is a curiously hard-looking fabric, which, it may be remarked, is one of the most favourite nurseries of the Cuckoo. The Marsh Warbler seems independent of water, except that, in the same way as its congeners, it relies largely for food on aquatic insects and their larvæ, while the flatter nest is never in reeds but is usually placed in rough herbage or small willows, meadow-sweet and willow-herb being specially favoured sites. The eggs are distinguishable by their white ground-colour and clearer markings. The Sedge Warbler is still less particular as to site or materials, but generally uses some moss; its five or six eggs, moreover, are of an almost uniform yellowish brown, owing to the closeness of the spotting. They often have a black streak at the larger end, as in the similar eggs of the Yellow Wagtails. Breeding takes place early in May; while the Reed and Marsh Warblers do not begin, as a rule, till late in the month.

Most people have heard of the Grasshopper Warbler or "Fen Reeler" (Locustella ncevia), so called from its 
notes, which resemble the soumds made by a cricket, a grasshopper, or the line rumning off a fisherman's reel. Certainly few would believe that they come from a bird's throat. Normally it only sings for a couple of months

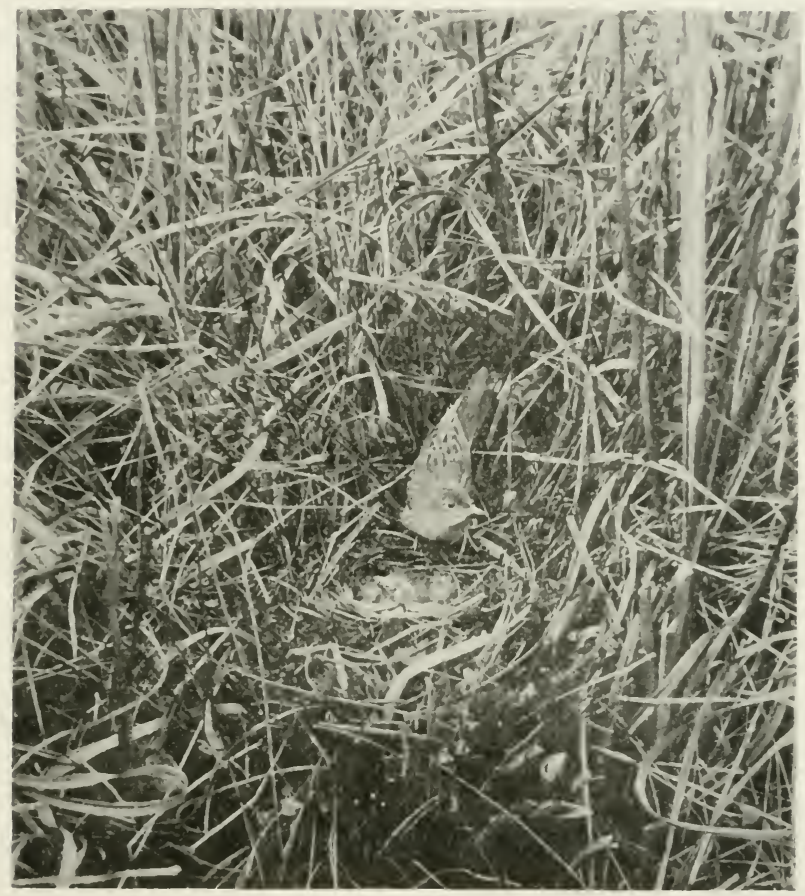

Grasshopper Warbler

after its arrival in mid-April, yet it does not leave the country till September, though, being local and irregular in appearance, it may easily be overlooked. Moreover it is a skulking species, which loves sedgy or rushy flats or coarse grass on banks and at hedge-bottoms, while 
it does not despise clearings in woods and heathery moors. Imaginative writers even talk of it creeping like a mouse. Wicken Fen in Cambridgeshire and the Norfolk Broads are favourite resorts, but the discovery of the nest, always a matter of difficulty, there becomes almost an impossibility except to sedge-cutters. It is composed of grass and a quantity of moss, and contains five or six lovely white eggs with dull pink stippling. This Warbler has a characteristic habit of spreading its tail on being flushed from the nest, a fact which draws attention to an otherwise inconspicuous brown bird with darker streaks above and lighter tints below. It ranges in Britain as far north as Skye, and over the continent of Europe south of the Baitic, with south Norway and Finland; but eastward the limits are doubtful. The food consists mainly of aquatic insects and their larvæ.

Savi's Warbler (L. luscinioides) was only recognised as distinct by Savi in 1824, though Temminck had previously seen a Norfolk specimen and determined it as a Reed Warbler. To our country it was always an uncommon summer migrant, but it probably bred regularly in the Norfolk, Cambridgeshire, and Huntingdonshire fens, if not in Suffolk, until its disappearance in 1856. Southward from Holland, where it is now much rarer than formerly, it is found scattered over Europe, reaching to north-west Africa and west Turkestan. Savi's Warbler resembles its congener in general habits, but has a far harsher note; in colour it is of a plainer reddish brown. The nest is most peculiar, being composed of broad sedge leaves or of the grass Glyceria aquatica; the eggs are marked with purplish grey instead of pink. 
Subfamly Accentorinæ, or Hedge-sparrows

We will now turn to the Hedge-sparrow and the Dipper, though the former has sometimes been placed nearer to the 'Thrushes, and the latter may possibly be akin to the Wren : the truth, which we should constantly bear in mind, being that no linear arrangement can ever accord exactly with nature, since a bird often exhibits striking affinity to species other than those to which it stands next in a list.

The Hedge-sparrow (Accentor modularis) is a resident or partially migratory species, the numbers of which are vastly increased by immigrants from the north in the cold season. It breeds far up our hills, though not in some of our bleakest islands, and occupies Europe from the northern limit of forest-growth to north Spain, as well as the Caucasus and Persia. Its shuffling gait on the ground, its weak flight, its mossy nest and five or six deep blue eggs are matters of ordinary knowledge, but its sweet note is sometimes mistaken for the less melodious strains of the Robin. The Hedge-sparrow breeds very early and rears more than one brood in the year, while it often acts as foster-parent to the Cuckoo. The nest may be found in low hedge-bushes, shrubs, heaps of brushwood, and the like, and almost invariably has a foundation of little dry twigs. In winter the bird will eat almost any scraps that are given to it, but the natural food is of insects, worms, spiders, and seeds. The colour is brown with blue-grey head and lower surface.

\section{Family CINCLIDÆ, or Dippers}

The Dipper (Cinclus cinclus) is one of many forms that occur in suitable spots throughout Europe and Asia, and extend to the Atlas mountains. By some our species 
C. c. britannicus is considered distinct. The WaterOusel, or Water-Crow, to use local names, is one of the most interesting of British birds from its striking appearance, its unusual habits, and its peculiar nest; it is a nice fat brown bird with a white chest and chestnut belly, which may be seen flitting from boulder to boulder on our rapidly running hill-streams, bobbing about on its stony perch and constantly diving into the

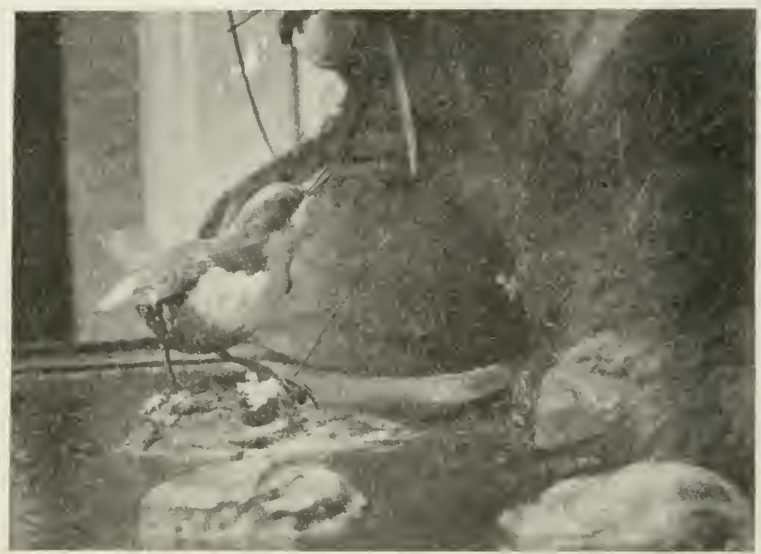

Dipper

water, where it uses its legs and wings below the surface. Naturally it is not suited by our southern and eastern counties, but it is found from Cornwall and Wales northward to the Orkneys, and also in Ireland, while its cheery song may be heard even in the severest weather in its upland haunts, which it seldom cares to leave. Its food consists of small mollusks, spiders, beetles, and insect-larvæ, and to some extent of .fishspawn, but its utility far outweighs its harmfulness. 
The nest is a big round ball of moss. or moss and grass, lined with leaves, generally of the oak or beech, and has a side entrance; it is built in a hole in a wall or bank, among protruding tree-roots on river sides or not uneommonly bencath a bridge or close to a waterwheel; in many cases it is stuck against a rock or large

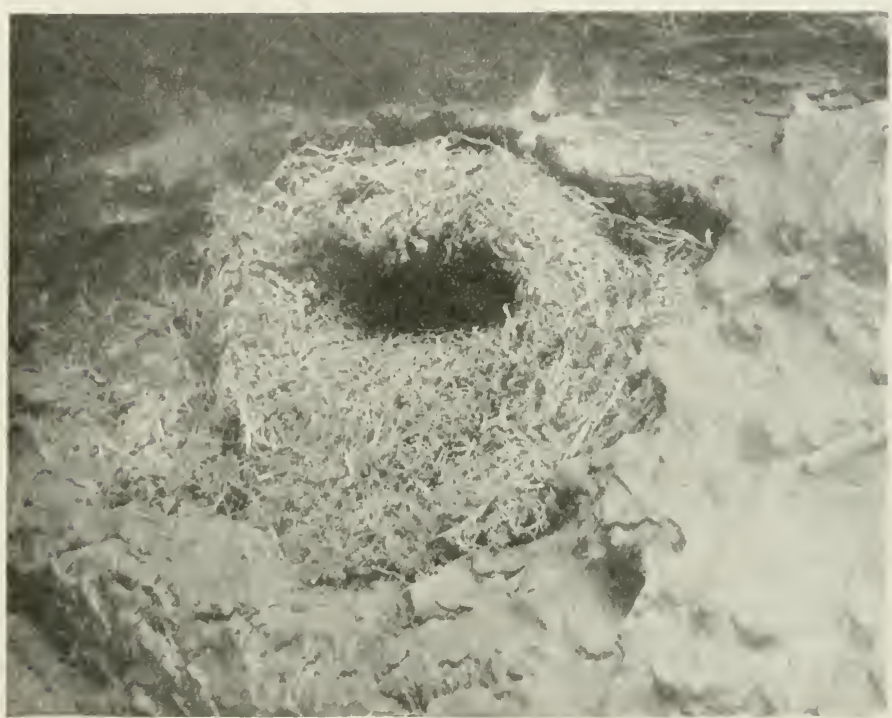

\section{Dipper's nest}

boulder with the slightest possible support. The five or six somewhat pointed white eggs are laid from March onwards, and a third set has even been known to have been deposited in the same nest. The fledglings swim at once. 
Family PANURID开, or "Bearded Tits"

This remarkable family, of doubtful position, contains only one British member (Panurus biarmicus), a

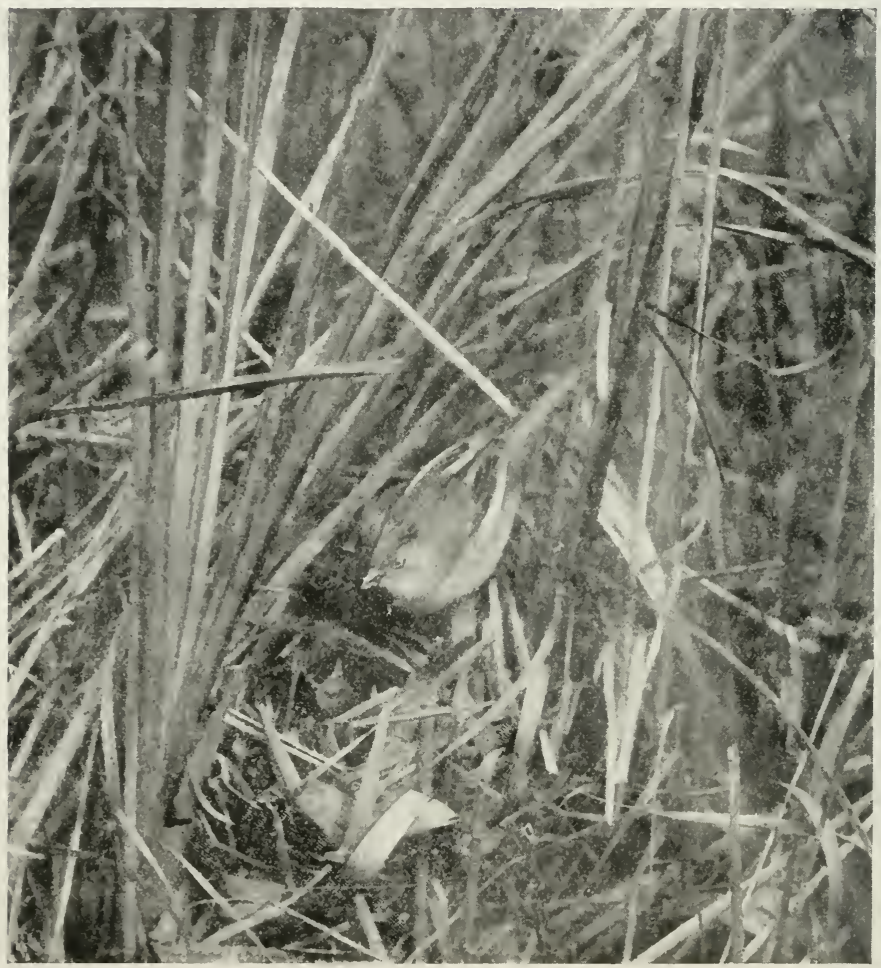

Bearded Tit

slender and chiefly fawn-coloured bird with long black cheek-patches and an inordinately long tail, from which it is called "Reed-Pheasant" in Norfolk. The male has a grey head, the female lacks the black on the face. It 
is now confined in Britain to the Broads and I)evonshire, but used to breed in other of the eastern and southern counties, and ranges abroad from temperate Europe to central Asia or even Manchuria, though limited by the fact that it requires large reed-beds to dwell in. These it seldom leaves even in the hardest weather, and there pairs or little parties may be seen by anyone who punts slowly past their haunts, flitting along the tops of the reeds, uttering their curious sharp note of "ping-ping," and soon dropping down in the vegetation. This note may even be heard in winter, and is only clearly audible on a calm day; in summer close observers may watch the hen building her nest of broad sedges or reeds and the cock bird supplying her with dry reed-flowers for the lining. The site chosen is always on the ground among the reeds, generally in open spots which hardly bear a man's weight, and eggs may be found from April to August; they are round and white with delicate blackish brown scrawls, and are about six in number. Many nests are cut over by the marshmen. The food consists chiefly of small mollusks and seeds of the reed, so that in almost every particular this species differs from the remainder of the Titmice, while its anatomy is certainly not that of a Parus. It has been introduced of recent years at Hornsea Mere in Yorkshire.

\section{Family PARID君, or Tits}

Titmice are familiar winter-guests of the householder, and are resident in our islands, or migrate to a comparatively small extent; in fact different scientific names have been given to distinguish them from the various continental or Asiatic forms. All but one belong to the genus Parus, and in strictness should be called 
Titmouses (German "meise "), though we hope that no one will follow such a practice. Our Long-tailed Tit (Egithalus caudatus roseus) is a local race of A. caudatus

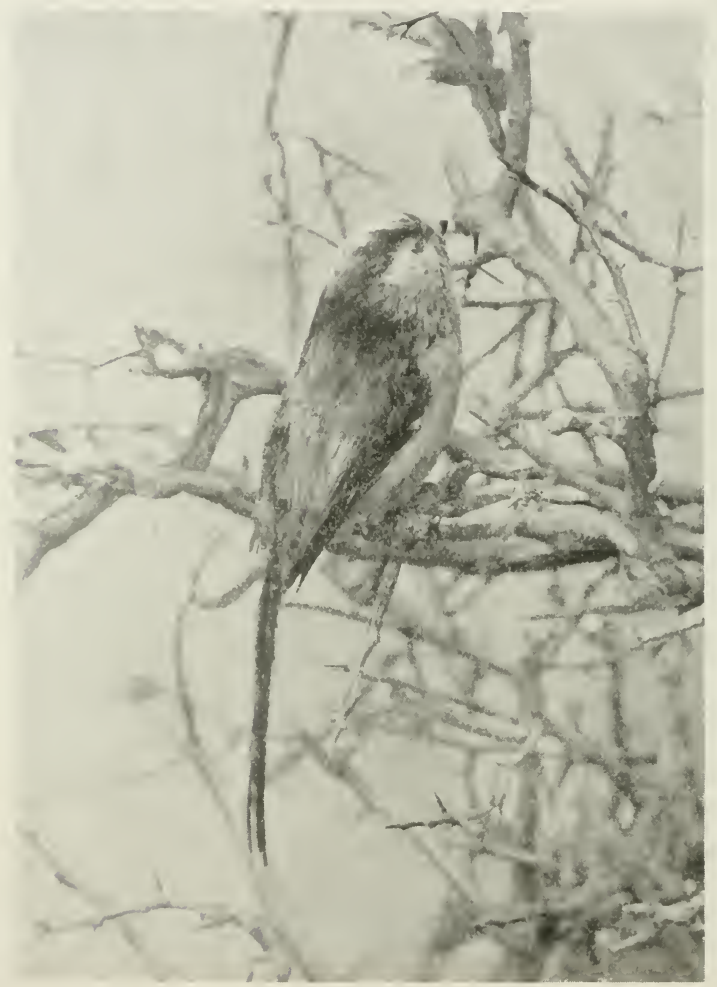

Long-tailed Tit

of Europe and Asia, and may also breed in France and the Pyrenees. It is distributed as far north in Scotland as trees occur, and over the rest of the kingdom is very seldom absent, though locally uncommon. The 
well-known nest is an oval ball of moss covered with lichens and warmly lined with feathers, while the beautiful fabric contains from seven to ten small white eggs,

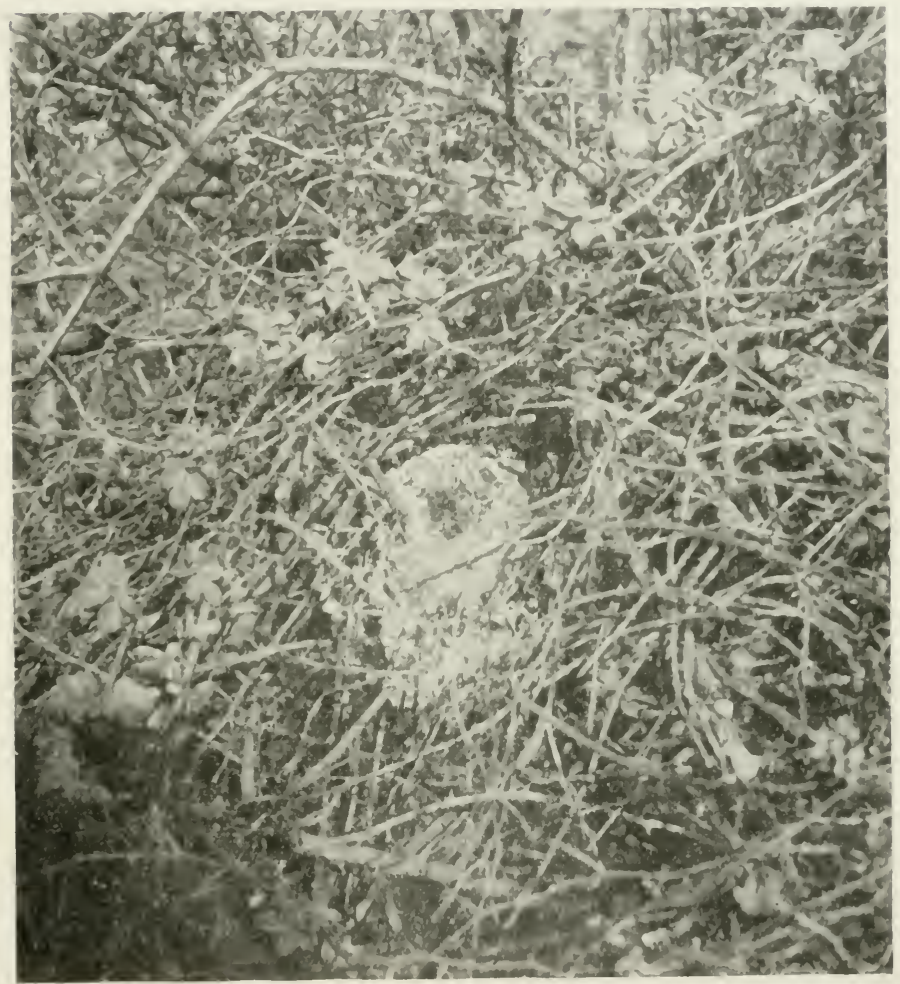

Long-tailed Tit's nest

generally with indistinet pink spots. Forks of lichencovered birches are a favourite site in north scotland; but thick hedges, gorse-bushes, small shrubs or the ivy on trees are commonly utilized; in various counties the 
bird is known as the "Bottle-tit" or "Feather-poke." After breeding these Tits keep in flocks, seeking for insects and larvæ, while they are more often seen than heard, for their notes are gentle; they fly pretty well, though unsteadily. The extremely long tail distinguishes them from other Tits, as does the black and white coloration, relieved by a rosy rump and belly best seen at close quarters.

The remaining species of Titmouse are all similar in their ways, flocking in winter, climbing about the trees, prying about the bark or leaves for insect-food, and laying from five to eight white eggs with bright red spots. But in certain points they differ. The three commonest are the Great, Coal, and Blue Tits, the Coal Tit usually predominating in pine-woods, and the others elsewhere. The Great Titmouse, or Oxeye (Parus major), which becomes rare in the north and north-west of Scotland, is sufficiently distinguished from its congeners by the broad black stripe down the yellowish under parts, though its black head and white cheeks are most conspicuous. In different forms it breeds south of the Arctic circle to the Mediterranean Islands, north-west Africa, Palestine, Persia, Burma, China, and Japan, while the British form has recently been separated from the others. It makes a nest of moss, surmounted by a felted mass of wool, fur and hair, in a hole in a tree or wall, when it does not choose a pump, a wooden letter-box, or other extraordinary situation. Its notes are comparatively harsh, and a rasping cry of two repeated notes which it often utters is commonly mistaken for that of the Chiffchaff; it also imitates the voices of other birds. The Great Tit is no doubt guilty of spoiling many fruit-buds, which may or may not 
contain harmful insects; it also eats peas, nuts, and seeds to some extent, and is always attracted by meatbones, suet, cocoa-nuts and the like, hung up for it in

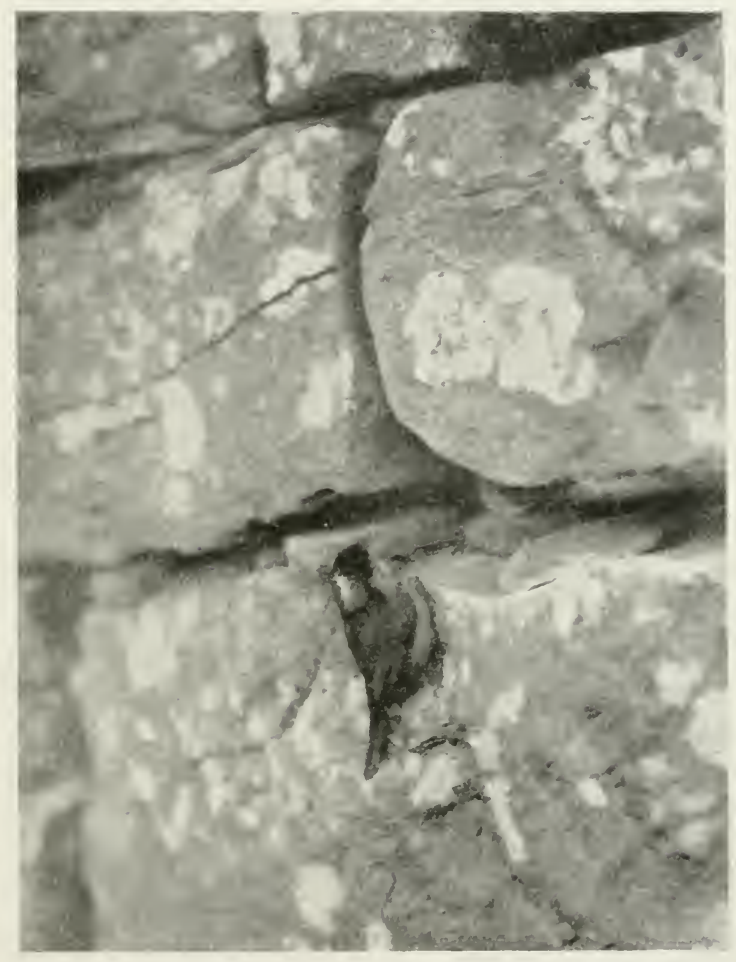

Coal Tit

winter. Occasionally it will even murder another bird, but insects are its staple food.

The Coal 'Titmouse ( $P$. ater britannicus), a smaller species with no black stripe down the breast, has the nape-patch as well as the cheeks white; it does not 
breed in the Orkneys or Shetlands and abroad is represented by $P$.ater, with grey in place of olive back. Specimens, however, which many people think indistinguishable from the latter, are found breeding in Scotland, and the Irish bird, with a yellow rather than a whitish breast, has been lately separated; the truth being that it is difficult to draw the line between forms so closely related. The call-note of the Coal Tit is sharp and loud, so that it cannot easily be mistaken for those of its congeners; the nest resembles that of the Great Tit, but is usually placed in a hole in a wall or stump or in the ground, less commonly in a bank-side or the thatch of a shed. The bird is not so fond of an artificial nesting-box as the Great and Blue Tits are.

Until the last few years our somewhat browner backed Tits with merely the cheeks white were all united under the name of Marsh Titmouse, though not necessarily found near marshes. It has been ascertained, however, that two forms have been confounded under that title, the Marsh Tit with shiny black head in the adult ( $P$. palustris dresseri) and the Willow Tit ( $P$. borealis kleinschmidti) with dull black head. Even yet perfect unanimity has not been arrived at, and every reader of these pages must form his own opinion ; but it appears that the birds breeding in Scotland and the Border counties of England should be referred to the Willow Tit, while further south both forms occur, with the Marsh Tit predominant in some or most of the districts, and especially in Kent. The latter seems to prefer woods, the former copses, hedgerows, and gardens. The Willow Tit cuts a neat round hole and lines the excavation with felted down, hair, and the like; the Marsh Tit does not usually cut its own hole and has a 
more decided substructure of moss. The Willow 'Tit's soft repeated cry resembles that of the Wryneck at a distance, the Marsh 'Tit's notes are merely somewhat sharper than those of the Blue or Coal 'Tits. Such at least is the writer's experience, and it is corroborated by that of others; yet further information is desirable, as the birds are only loeally common, and it is no easy matter to find a nest in such a position as to enable the observer to lift the parent bird off the eggs and examine it. Irish birds also need further examination.

The Blue Titmouse ( $P$. corruleus) with its blue crown and nape, black throat and streak across the white cheeks, and yellow breast is a very familiar object in our gardens at any season; it does not extend in summer to the northerly isles of Scotland and similarly shuns the more Aretic parts of Europe. Otherwise it occupies the whole continent exeept Spain-in a form rather brighter than ours-and meets south of the Mediterranean and in Russia other allies which are sufficiently distinct to be characterized as species. Whether flitting along our hedgerows, hanging pendulous in search of insects on the trees, or engaged in building a nest in some hole of a tree or wall, the Blue Tit is always the same brave confiding little bird, which hisses violently at us when eaught on its eggs, and resembles the Great Tit in its fondness for nest-boxes.

The Crested Tit ( $P$. cristatus) is partieularly interesting from the fact that it is confined in Britain to the ancient forests of the Spey and its tributaries. It has never been actually proved to breed elsewhere in Scotland, but a slightly different form oceurs in many parts of the Continent. This local species is brown, with buffish white under parts, having the head and neck beautifully 
marked with black and white, the crest pronounced and erectile. In habits it is not unlike other Tits, but its note is rather loud and very characteristic. It inhabits Scotch fir woods, but does not invariably bore its nestingholes in dead pines, as it occasionally chooses hardwood trees, or even ready-made holes in wooden or iron posts. The eggs are seldom more than six or seven and are particularly brightly marked.

\section{Family REGULID訛, or Gold-crests}

A very familiar bird is that smallest of British species the Gold-crested Wren (Regulus regulus), which ranges over Britain, as well as Europe, to the Caucasus and Asia Minor, within the limits of tree-growthexcept Spain and Portugal. The continental form is hardly, if at all, distinguishable from that which occurs in this country, while it is one of the curious facts of nature that this delicate looking little creature migrates to and fro in immense flocks in autumn and spring, often for weeks together. We are never without the bird, which is often found in company with Tits. Its call-note is somewhat similar, but it has also a low song. It is fond of searching for its insectfood on fir trees, especially spruces, and on the latter it usually builds its beautiful little mossy nest lined with feathers, which is slung like a hammock under the tip of a bough and contains from five to ten white eggs ringed or covered with reddish buff markings. Alternative sites are the ivy on tree-trunks or small bushy conifers.

Constantly confounded with our common species is that rare immigrant the Fire-crested Wren ( $R$. ignicapillus), which is also an olive-green bird with an orange 
crown margined on each side by a black band. Little reliance can be placed on the colour of the crown in males as a distinction, but the Fire-crested Wren is more sulphur-green on the neck and has a distinct black line through the eye. The females have lemon-yellow crests, the young have none. The last-named species does not range further north than the Baltic, but is the more common in some parts of southern Europe and of north-west Africa; it also breeds in Asia Minor.

\section{Family SITTID开, or Nuthatches}

The Nuthatch (Sitta caesia), notwithstanding its loud whistling spring notes, is a shy bird, which attracts little attention as it creeps quietly about the treetrunks or flies heavily to a new hunting-ground of the same description in search of insect-food. The grey upper parts are not conspicuous and the buff breast is hardly more so. Nowhere really common, it is generally found in well-timbered districts and especially old parks, while it is only a casual visitant to Scotland and perhaps Ireland; the foreign range extends over Europe with the exception of Scandinavia and Russia, where a whitebreasted form occurs, and Corsica, where there is a distinct species. As in the case of most of our residents it breeds early, choosing a hole or crevice in a treeor more rarely in a bank-and lining it thickly with dry leaves or fir-scales, upon which lie the six or more white eggs with red and lilac spots, similar to, but larger than, those of the Great Tit. The nesting-hole is plastered up with mud, so as to leave only a circular entrance. This species is known as the Nut-jobber from its habit of hammering open with its powerful bill the nuts of which 
it is fond, and it is a pretty sight to watch it at work upon a hazel-nut stuck in the chink of a post. The winter notes are Tit-like, the spring notes shrill, the summer cries vary.

\section{Family TROGLODYTIDÆ, or Wrens}

Wrens have a wide range in the world, and unlike most Palrarctic families extend to temperate South

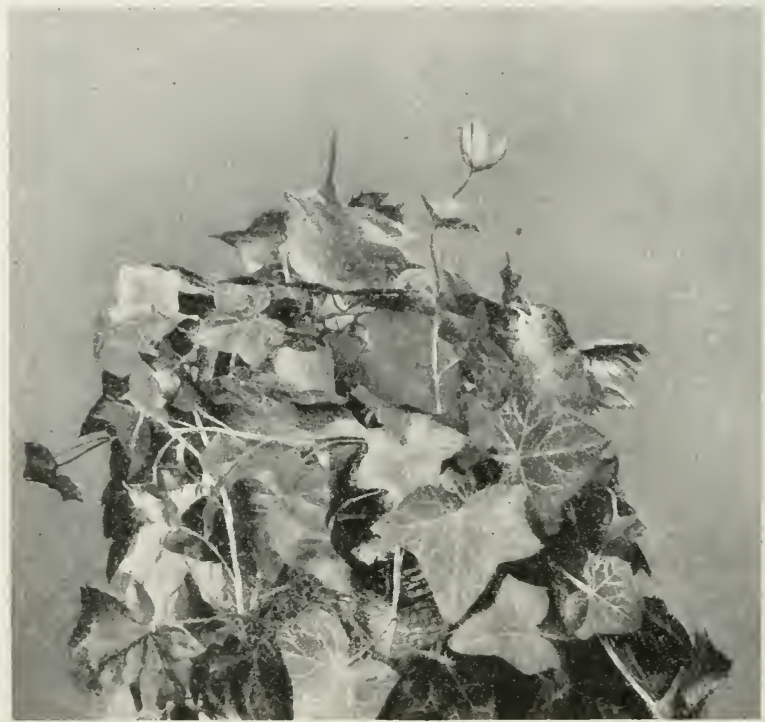

Wren

America; nevertheless we have only one British species (Troglodytes troglodytes), which is too common to need many details. Its simple but joyous song cheers us even in winter, and there are few road-sides where we do not often catch a sight of its restless little brown 
body and uptilted tail; it is found far up our hills and in our bleakest islands, while the numbers are increased in winter by migrants from abroad. The well-known big oval nest of moss, dry leaves, ferns, or

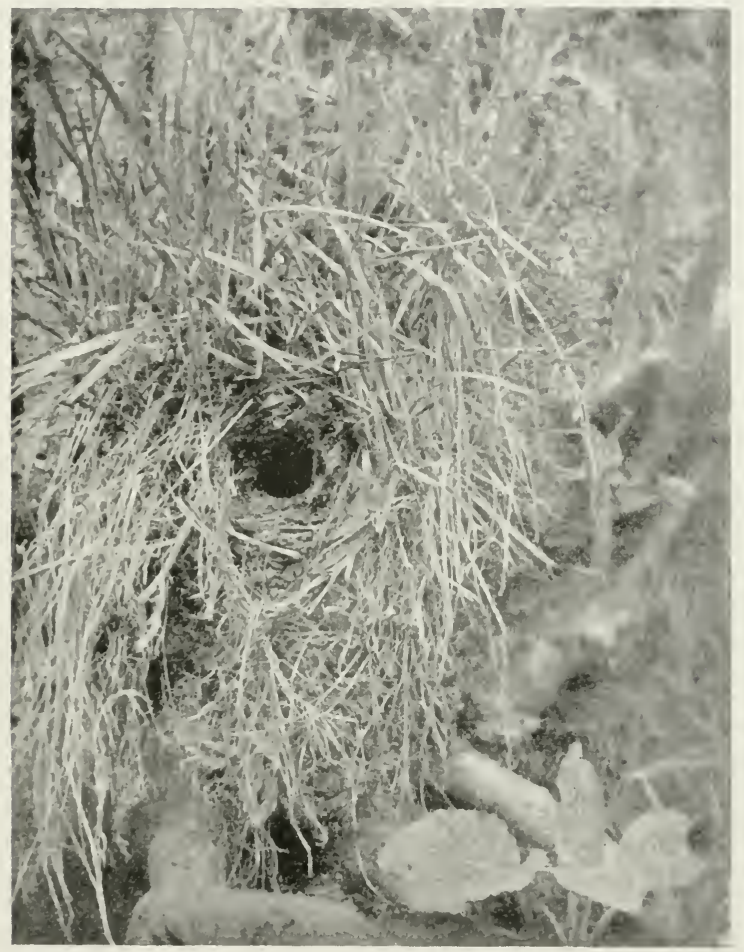

Wren's Nest

the like is often placed in most curious positions; the elongated white eggs are much less spotted than those of 'Tits, and are from six to ten in number. Our form of Wren occupies all Europe and does not reach west 
Asia or north Africa, but variations in size and colour have caused examples from Iceland, the Færoes, Shetland, and St Kilda to be considered distinct subspecies.

\section{Family CERTHIID无, or Tree-creepers}

The Tree-Creeper (Certhia familiaris) is found in Europe, northern, eastern and central Asia, and North

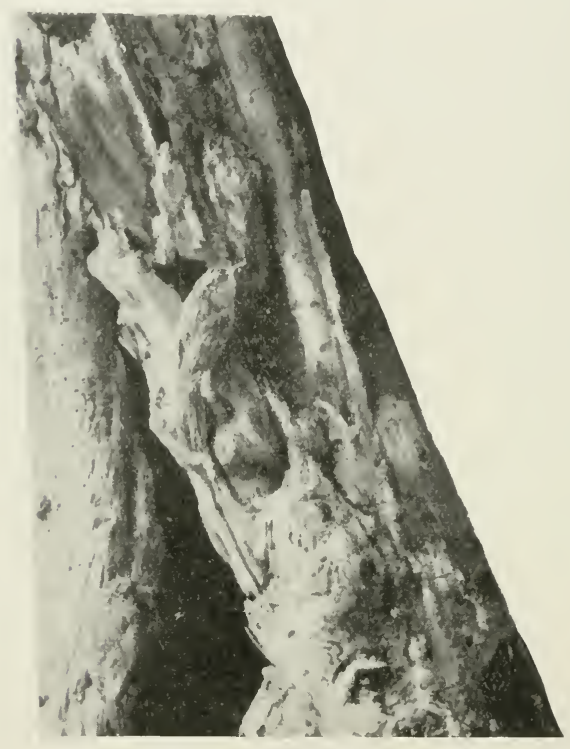

Tree-Creeper

America, and, as might be expected with so widespread a species, has been split into innumerable subspecies, with which we cannot concern ourselves here, though it should be noted that our race has been named c. familiaris britannica. Being a quiet little brown bird with whitish under parts it may easily escape notice, 
but it is never particularly common, though it is well known to country-folk as the Woodpecker, from its habit of creeping up the trunks and branches of trees, supported by its stiff-pointed tail feathers. The beak and claws are long and curved. Though it will eat seeds, the proper food consists of insects, in search of which the Creeper works spirally up a tree, finally flying off to begin at the base of another. It has a very low sweet song and a sibilant call-note. The nest has a foundation of small twigs below the main material of a little roots, grass, or moss, the interior being thickly lined with feathers, on which lie six or more very thin-shelled white eggs with red and lilac markings, like and yet unlike those of a Blue Tit. The nest should be looked for behind loose slabs of bark, but may be placed under eaves of sheds, in crevices of walls, or even in the foundations of large birds' nests, as is sometimes also the case with Tits.

\section{Family MOTACILLID $\nRightarrow$, or Wagtails and Pipits}

A certain similarity may be observed between Wagtails and Pipits in their general habits, notes, and even nests and eggs, while systematists may now be said, on anatomical grounds, to be unanimous in combining them in one Family, though the Pipits have undoubted affinity with the Larks as well. The Wagtails are slim, lively, and confiding little creatures, with jerky undulating flight and a characteristic habit of keeping the hinder part of the body in constant motion when on the ground. It is very amusing to watch them on a grassy flat or a garden lawn; they make impetuous darts after insects for a yard or two, suddenly stop and almost fall forward on their heads to secure their fly or 
worm, and then make a fresh dart forward, or run with twinkling feet for a considerable distance. Ever and anon they fly up in the air after their prey, but this habit is more evident when they flit from stone to

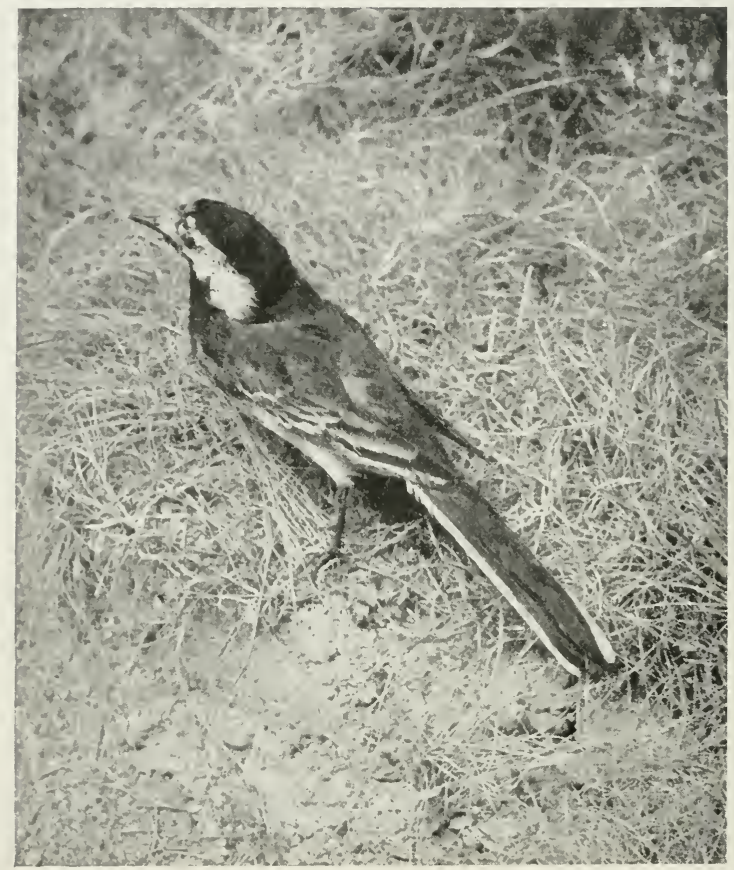

Pied Wagtail

stone along a stream. Our Pipits have shorter tails than our Wagtails, and all are characterized by more or less white lateral tail-feathers. The Pied Wagtail, Water Wagtail, or Dishwasher (Motacilla lugubris) is our resident black and white species-resident, that is 
to say, in appearance, though large numbers pass to and from the Continent in autumn and spring, and even in Britain none are to be seen in the far north in winter. Abroad it breeds in Holland, Belgium, and north-west France, if not in south-west Norway; but in Europe generally, and perhaps even northern Africa, the representative form is $M$. alba, whether it be considered a distinct species or not. This form has, in the male, a light grey instead of black mantle, while even the females are much lighter. The young are less easily distinguished; and when, as is rarely the case, $M$. alba is reported as breeding in England, the male should always be carefully examined for fear of error.

The song is short and not very noticeable, but the sharp double call-note is familiar to all who live near water-sides in spring, for the birds must then always be near water, though the smallest runnels will often suffice. Later in the year they frequent our lawns and are common on the sea-shore. The nest is placed in a hole in a wall, bank, quarry, refuse-heap, or pollard willow, or among tree-roots projecting from a streamside; it is made of grass or roots and lined with hair and feathers. The half-dozen eggs are greyish white with small dark grey or blackish spots.

The beautiful Grey Wagtail (M. boarula) is to be seen throughout the year in the valleys of our hillcountry, though very rarely at lower levels except towards winter; it is perpetually confounded with the Yellow Wagtail on account of its bright yellow breast, though its crown and back are grey and its throat black. This species ranges from south Sweden and mid-Russia to the Mediterranean, closely allied forms occurring in the Azores, the Canaries, and Asia. Holes 
in masonry, ledges of rocks, or projecting tree-roots by streams are the almost invariable sites for the nest; the structure is more mossy than in the Pied Wagtail, and the eggs are closely marked with brownish yellow. The true Yellow Wagtail ( $M$. raii), which is greenish olive above and yellow below with browner wings and tail, is only a summer visitor to us, and frequents marshy flats, water-meadows and such places, though not uncommonly placing its nest in young corn or rye-grass. It is always built on the ground, in some depression of the soil, and is similar to that of the Pied Wagtail, though the eggs are even yellower in their markings than those of the Grey Wagtail, and have often the same black hair-line at the larger end. The Yellow Wagtail breeds locally in south Scotland, and also in western Holland and western France; it is, however, impossible in our limited space even to name the many allied forms that occur abroad. The best known in Britain is the Blue-headed Wagtail (M. flava), which breeds irregularly with us, chiefly in the south and east of England, and is common in most parts of the Continent; adults may be distinguished from those of $M$. raii by the blue-grey head and the white in place of yellowish stripe over the eye. In the adult male of the latter the crown is almost yellow.

Three Pipits breed with us, besides accidental visitors, and two are resident or partly migratory. Of these the best known is the Meadow-Pipit or Titlark (Anthus pratensis), abundant on our moors and by no means rare on rough ground at lower altitudes. It is found throughout Britain; from Iceland to west Siberia; and thence to the Pyrenees, north Italy, and 
Palestine; south of which limits it is practically a bird of passage, for $A$. bertheloti of Madeira and the Canaries is considered a distinct speeies. As the Titlark is a plain streaky brown bird with white breast striped with the same colour, it would not be specially conspicuous, were it not for its habit of soaring a little way up in the air to utter its shrill song, and flying restlessly round an intruder while giving vent to the sharp alarm notes, which account for one of its names; this generally takes place near the nest-a plain cup of bents placed in some depression of a rough grass field, on a bank, or among heather-which contains about five white eggs very thickly marked with brown. The Cuckoo is often reared by this species, and almost invariably so on the moors, which afford the regular food of insects, worms, small mollusks, and seeds in abundance.

The less demonstrative and more local Tree-Pipit (A.trivialis) differs little in appearance, but has a much shorter and more curved hind-toe. It only visits us between April and September, and is not found in the northern islands of Scotland or in Ireland. Except for Iceland and the Froes, the foreign range is much as in the last species, though a separable race extends further eastward, to Japan and China. In habits, however, it is absolutely different, for it frequents open copses or the outskirts and rides of woods, where it pours out its sweet notes while sitting on the tree-tops or while soaring to a considerable height in the air above them. Away from these quarters it is seldom seen, and there it builds a similar nest to its congeners, but lays very remarkable eggs. No British bird, except the Guillemot, shews such a range of coloration in the markings, 
which may be purple, red, rich brown, or almost black, while the pinkish or greenish ground-colour varies in accordance. In Scotland the Tree-Pipit is often called "Wood-Lark," a very natural mistake where that species does not occur.

The Rock-Pipit (A. petrosus) is larger than the Meadow-Pipit, and rather more olive, while the outer tail-feathers are marked with smoke-colour rather than white. It is entirely confined to our rocky shores, but ranges abroad from Norway to north and west France; elsewhere matters are complicated by the occurrence of a form with a reddish breast. Since Meadow-Pipits also breed on our cliffs, observers must be careful in their identification, for the habits as well as the plumage are similar, and both birds feed on the shore after the breeding season. The Rock-Pipit's eggs are merely a little larger.

\section{Family ORIOLID $\nexists$ F, or Orioles}

The Golden Oriole (Oriolus oriolus) might be relegated to our list of irregular migrants, were it not for the fact that it now breeds in Kent and occasionally in our eastern and southern counties. All should therefore be on the look-out for a beautiful bird of the size of a Thrush, golden in colour with black wings and tail, and use every means to preserve it, if seen, or permit it to breed in safety. The nest is a sort of cradle of grass, wool and bast, slung in the fork of a branch ; the large eggs are white with round purplish black spots. The Golden Oriole has a swift but heavy flight, a lovely flute-like song and a harsh call, but it eats too much ripe fruit to be popular abroad, though insects form part of its diet; it often frequents town 
gardens in Europe, south-west Asia, and north-west Africa, and is one of the brilliant members of a large family extending over a great part of the globe. 'The female shews little yellow.

\section{Family LANIID无, or Shrikes}

The only member of this family that breeds regularly in our islands is the Red-backed Shrike or Butcher-

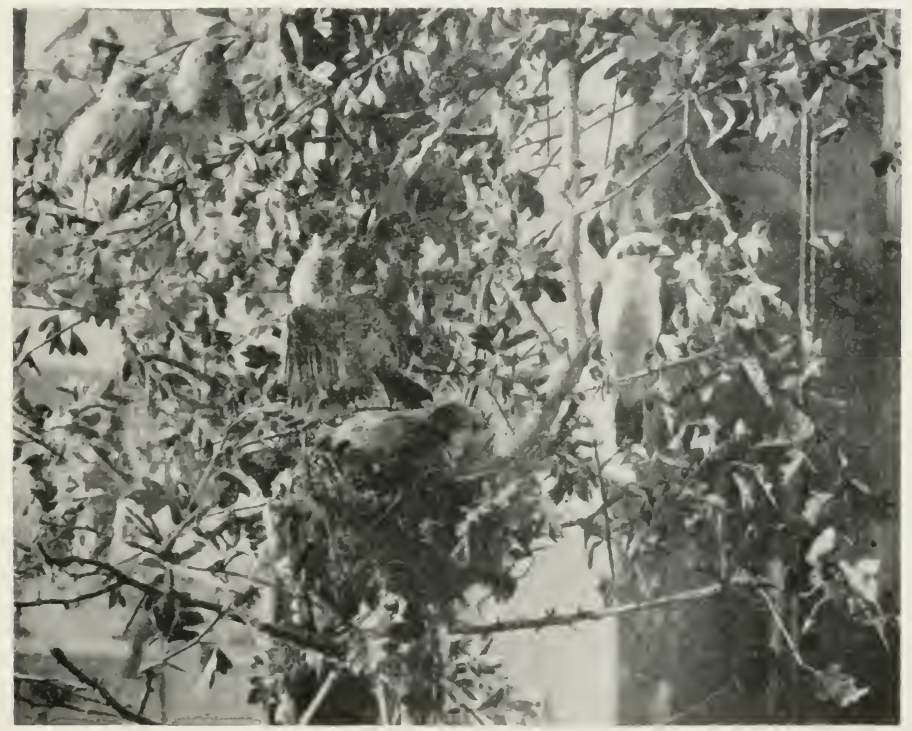

Red-backed Shrikes

bird (Lanius collurio), which gradually decreases in numbers as far north as southern Scotland and is only a straggler to the north of that country or to Ireland. Arriving early in May it is a conspicuous object as it sits on the tops of bushes, telegraph-wires, and the like, 
while its big nest of grass and moss is hardly less conspicuous than the bird itself, in the solitary hawthorn bushes which it selects by preference. It may, however, be placed in a thick hedge or shrub, or on a low branch of a tree, while it is always lined with wool and hair, and contains some five eggs varying in tint from reddish to greenish white, with fine blotches or spots of the corresponding colour, not uncommonly collected into a zone. This Shrike is very wary, but fairly bold in the breeding season, after which it is little seen till its departure in August: it feeds on small mammals and birds, beetles, bees, and other large insects, and occasionally keeps a small stock impaled on thorns near the nest. These "larders," however, are not so common as has been supposed. For short distances the flight is strong, while the bird has a harsh and somewhat Chat-like note, as well as a slight song. The foreign range extends over northern Europe and Asia to Transcaspia and north Persia, and over southern Europe exeept the Iberian Peninsula. The male is chestnut-brown above with grey head, black and white tail, and black face, and pinkish buff below; the female is red-brown above, and whitish below with crescentic markings recalling those of some hawks.

The Woodchat Shrike (Lanius senator), distinguished by its chestnut head and white wing-bar, is a common continental species which visits us at very irregular intervals, but must be mentioned here as having possibly bred twice in the Isle of Wight. It is therefore one of the birds for which a watch should be kept in the south.

Besides these we have two other members of the family that occur in Britain, the Great Grey and the 
Lesser Grey Shrikes. The latter (L.minor) is only a straggler from south and central Europe, but the former (L. excubitor) is a pretty regular immigrant in the cold season, especially to our eastern coasts, though it has never been known to breed with us. It comes from northern and central Europe, but the range can hardly be defined here, on account of the various species or races that have been described from Europe, Asia, north Africa, and North Ameriea. It is very doubtful whether the form that oceasionally visits us, with one white wingbar (L. major), is separable from the typical form with two bars. The colour is grey above and white below, with black cheeks, wing- and tail-feathers. The nest is larger than in the ease of the Red-backed Shrike, and the eggs are greenish white with olive markings.

\section{Family AMPELID $\nRightarrow$, or Waxwings}

Perhaps the most beautiful of our constant but irregular visitors is the Waxwing (Ampelis garrulus), a bird of many colours. It is mainly fawn-brown, with more chestnut head, crest, and lower tail-eoverts, black cheeks and throat, and with yellow and black on the wings and tail. Added to this the tips of the shafts of the tail-feathers and of many of the secondaries are wax-like and scarlet. In some years few visit us, in some great numbers arrive, chiefly on our northern and western eoasts, and may be seen satisfying their hunger on the berries untouched by the other birds; they generally come in our hardest winters, driven from their summer haunts in Aretic Europe and Asia, where they are very changeable in their breeding quarters, which extend eastwards at least to Alaska and the Roeky Mountains. The nest was unknown until Wolley procured 
it in Lapland in 1856, and is an unusual structure like a platform of twigs, surmounted by a large open cup of lichens and grass; the eggs also are of a peculiar grey-blue tint with roundish blotches and streaks of blackish brown and lilac. The Waxwing's low continuous note is not much heard, and the bird is shy in

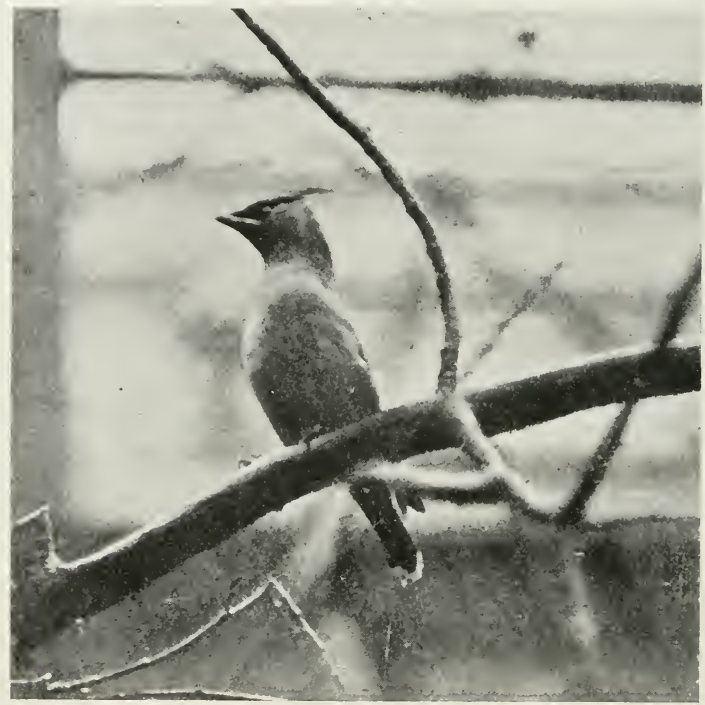

Waxwing

summer, when its food consists mainly of insects. Its flight is strong and often high.

Family MUSCICAPID出, or Flycatchers

We next come to a much more modest species, the plain brown Spotted Flycatcher (Muscicapa grisola), so called from its streaked breast; it is very late in arriving from the south, and only remains with us 
from May to September, while it ranges over the Palcaretic region eastwards to Lake Baikal and Dauria, except the extreme north. The low but pleasing song and the sharper call-note are familiar to most of us, and may even be heard in London; but this confiding bird is best known from its habit of sitting on a post,

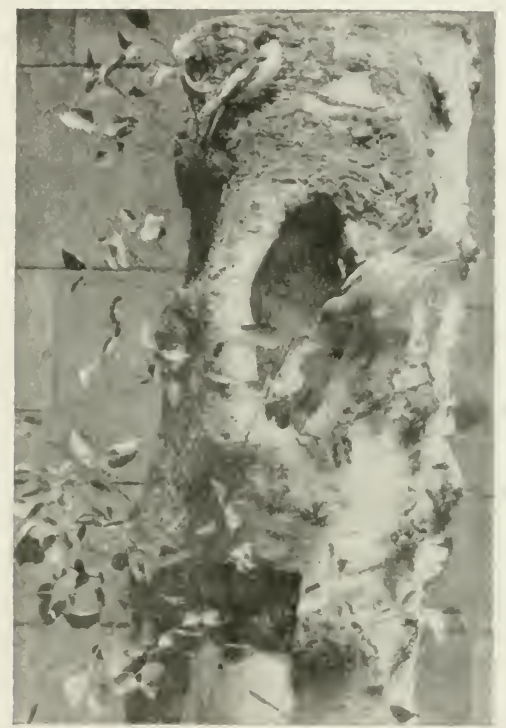

Spotted Flycatcher

stake, or the outer branch of a tree, whence it is constantly darting out after the insects which it eaptures on the wing. Thus it is often termed Post-bird, and another name is Beam-bird, from its fancy for a beam on which to place its nest. More common sites, however, are creepers on buildings, hollows in broken or pollard trees, and holes in walls, besides many curious positions.

E. B. 
The five pretty eggs are spotted with rufous on a greenish-white or even a green ground, and lie in a mossy nest, lined with warm materials, and often adomed with lichen. This species does not breed in the Hebrides, Orkneys, or Shetland.

That much rarer bird the Pied Flycatcher ( $M$. atricapilla) has a more restricted range abroad, where it only extends southward in its various forms to north Africa and eastward to Persia and Palestine, while, being a particularly arboreal species, it is decidedly local. In Britain, where it remains from May to August, it breeds chiefly in the west, from south Wales to Cumberland, irregularly in Scotland, but not in Ireland. Artificial boxes in our shrubberies have proved a great attraction to this bird, a somewhat curious fact, as it naturally frequents water and seldom leaves the sides of open shady streams, where it makes a pretty picture as it flits, Warbler-like, from oak to alder or ash, often uttering its sweet little song, and the male in particular exhibiting his bright black and white colours in contrast to the brown female relieved by dusky white. The insect-food is very commonly taken on the wing and conveyed straight to the brooding hen. The nest is composed entirely of roots and grass lined with hair, and thus can easily be distinguished from that of the Redstart, which has precisely similar pale blue eggs. It is always in a hole, and generally in a tree.

\section{Family HIRUNDINID丑, or Swallows}

Three members of this family are common and well known in Britain, the Swallow (Hirundo rustica) with long streamers or outer tail-feathers, chestnut throat and buff under parts separated by a metallic 
blue chest-band, the House-martin (Delichon urbica) with shortly forked tail, conspicuous white rump and lower surface, and the Sand-martin (Riparia riparia), which is not blue-black above like the others, but is brown with a mottled band of the same colour on the white breast. It has, moreover, a tuft of feathers above the hind-toe. All three have very short beaks with a wide gape. It will be seen below that the Swift is not a Swallow, but a "Picarian" form allied to the

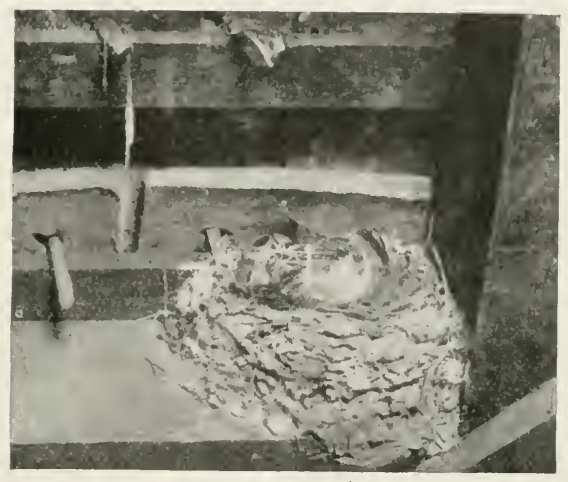

Swallow's nest

Humming-birds. The nesting habits are as distinet as the coloration, for both the Martins breed in colonies, while the Swallow does not. It builds an open cup with pellets of mud, and lines it warmly with straw and feathers to hold the five or six white eggs with brown and greyish markings; the House-martin sticks a half-cup of the same substance, with an aperture at the top of one side, under eaves, in window corners, under rock-shelves or mouldings at the top of bridges, adds a beclding of straw, chaff, or softer materials, and 
lays four or five pure white eggs ; the Sand-martin makes a grass or straw nest thickly lined with feathers at the end of a tumnel, which it bores in a bank or even a big heap of sawdust, and also lays white eggs. Sometimes it uses a hole in a wall.

All these species are migrants, and are with us from about the end of March to November at the latest,

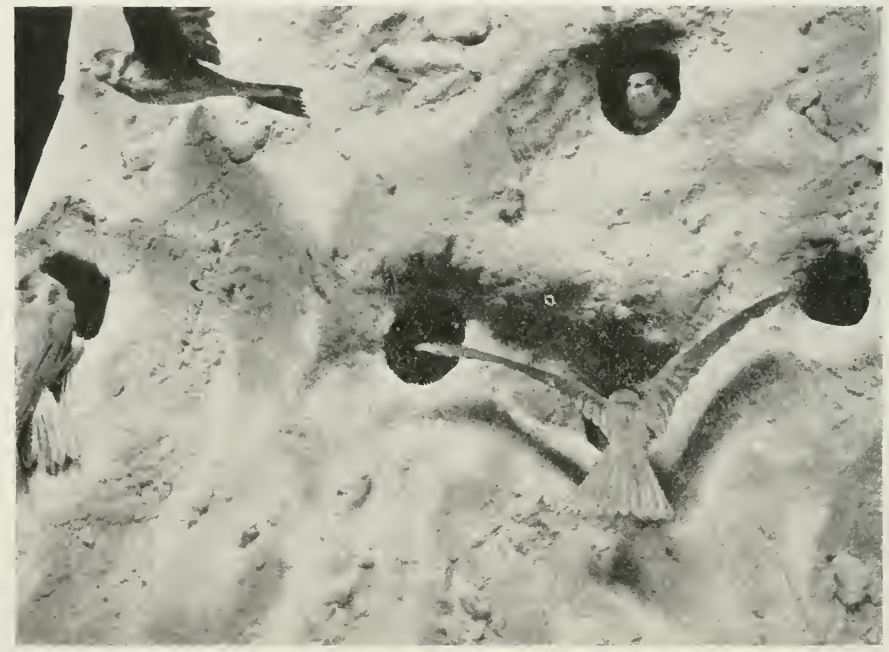

Sand-martins' burrows

but the Sand-martin is generally observed first and departs a little earlier; moreover, it breeds in the Nearetic region, in north-west India, and on the Nile, as well as in the Palæarctic region, while the other two species are confined to the latter. So too it is found in the Neotropical region as well as in the south of the Old World in winter, while the typical forms of the Swallow and the House-martin do not migrate to 
America, though they go further south in Africa and reach the Cape of Good Hope. When about to leave for their winter-quarters, the members of this family collect into flocks, especially in the case of the Swallows, which just before crossing the sea may be seen massed on roofs, telegraph-wires, and so forth, or even crowded together in huge quantities on the roads. The twittering notes and the flight are well known to everyone; the food consists of insects taken in the air or from the surface of the water. The birds always seem too busy to be shy, and are too quick and irregular in their movements ever to be in much danger from shooters; occasionally, however, they take it into their heads to attack a man, swooping down with much noise and brushing him with their wings, for no apparent object. Swallows commonly perch on trees, Martins rarely. All may have two or even three broods, especially when their first nests are usurped by Sparrows.

\section{Family FRINGILLID $\$$, or Finches and Buntings}

The members of this very large Family are for the most part stout-looking birds with strong bills, which feed mainly upon seeds and fruits, though the diet of the young consists also of insects and their larvæ. They vary considerably in size and coloration, as may be seen from the Sparrow and Linnet; the Hawfinch and Crossbill; the Goldfinch, Bullfinch, and Chaffinch; the Common, Yellow, and Snow Buntings. The subfamily Fringillince contains the true Finches, where the mandibles fit closely together, the subfamily Emberizince the Buntings, where the bill, when shut, shews a distinct gap. This seems a small point, but the subdivision is in agreement with the appearance and habits of the birds. 
Subfanily Fringillinæ, or Finches

The Greenfinch or Green "Linnet" (Chloris chloris), one of our most familiar residents, breeds throughout Britain and Europe generally, south of the Shetlands and the more Arctic districts; it has also been reported from western Asia and north-west Africa, but southward and eastward closely allied forms forbid exact limits to be defined. The olive-green colour, relieved by a little bright yellow and blackish brown, is best seen as the family parties flit before us along the hedgerows in summer, while in the breeding season the monotonous droning call-note is most usually heard as the bird sits unseen in the dense foliage. The flight is strong, and large numbers arrive from abroad towards winter; the song is feeble, and the flocks on the stubbles are pretty quiet. The nest, placed in a treetop at some height from the ground, in a shrub or a hedge, is composed of roots, moss and wool, and lined with wool, hair and feathers; the four to six eggs are greenish or reddish white with red-brown spots, as in a true Linnet.

The Hawfinch (Coccothraustes coccothraustes) is a most interesting species of peculiarly heavy build, with a comparatively short tail and immense beak; it used to be a rare resident in England, and is still extraordinarily erratic, but has certainly spread northwards of late years to Dumfriesshire and Fifeshire, besides becoming locally common in the south. It breeds throughout the Palæarctic region, except the more northern parts, if we do not separate the eastern Asiatic and other supposed western forms. Its food consists of seeds and fruits, such as haws, beech-mast, kernels of cherrystones, and peas, with caterpillars for the young, 
so that it finds its strong beak of the greatest use. Rows of peas are often nearly stripped when the young have left the nest. This structure, composed of roots and grass, often with an admixture of lichens and a base of twigs, is placed in the fork of a large hawthorn or fruit-tree, if not towards the top of a pollard or on some horizontal branch, and contains five or six curious bluish or greenish eggs with fine olive and greyish markings, which may be either spots or scrawls. Breeding takes place in May, when the bird is remarkably shy, as indeed is its usual habit. The flight is laboured. The characteristic whistle, however, soon draws attention to it; the song, on the other hand, is inconsiderable. After the nesting season the Hawfinch often wanders about the country, and it is then that we not uncommonly hear reports of a big fawn-coloured bird with a black throat, grey neck, and blue and white on the wing having been seen in a garden.

The Goldfinch (Carduelis carduelis britannica), one of the few species that live not unhappily in a cage, though a delicate-looking bird of the Canary type, is also partly fawn-coloured, but is beautifully marked with red, yellow, black and white. It is difficult to form a clear idea of its numbers in England as, after a serious decrease in the nineteenth century, it seems to be undoubtedly increasing again; but nests might now be found in any county, while such has been the case across the Scottish Border even as far north as Perthshire and Skye. Many migrants pass to and from the Continent at the usual seasons, and scientific names have been given to several more or less distinct forms ; it is impossible, therefore, to lay down any exact limits for each, but they occur throughout Europe, north 
Africa, and western Asia. The bird's fondness for the seeds of thistles, groundsel, and other composite plants is unfortunately well understood by birdcatchers, who take many individuals in their clap-nets when and where they have no business to do so; but the sweet song is little appreciated save in captivity, though country-folk are generally able to recognise the clear call-note. The Goldfinch often escapes observation as it passes lightly above our heads, for its bright colours shew up badly on the wing; while the nest, a pretty little cup of moss and wool with the softest of linings, is usually well hidden at the top of a fruit or other tree, though occasionally placed in a hedge or shrub. The four or five eggs are very pale bluish white with purplish or blackish spots.

The Siskin (Spinus spinus) is comparatively rare, and in Britain only breeds regularly in eastern and southwestern Scotland and in Ireland, though occasionally in various English and Welsh counties where spruces and larches abound. From autumn to spring, however, flocks are seen in many other districts, feeding on the seeds of the alders and ragwort or flitting about the country-side; yet the bird is local with us and also abroad, where it inhabits northern and central Europe and Asia as far as Japan. Perhaps it is best known in cages, for it is a favourite on account of its sweet, if not varied, song and the bright colours of the male, which is greenish olive with yellow breast and rump, black and yellow wing and tail markings; and also has a black crown and throat. The female shews much less yellow and no black above and is streaked, especially on the whitish under parts, with brown. The flight, the nest and eggs are much as in the Goldfinch, but the 
nest is usually high up in a silver fir or larch, and placed on a horizontal branch; sometimes it is much nearer to the ground or even in a bush. The substructure is commonly of little twigs and the eggs are bluish in tint with dark spots.

We need not enter into any details about the colour or habits of the House Sparrow (Passer domesticus), but may observe that the harm it does by interfering with the nests of the insectivorous Martin and devouring grain is to a great extent counterbalanced by its destruction of insects and their larva. South of the Aretic Circle the Sparrow is said to range to Spain and Austria and also to Irkutsk and Dauria in Asia, but it is only found near the dwellings of man, and is represented in parts of south Europe by the possibly distinct Italian and Spanish Sparrows.

A second resident species, the Tree Sparrow (P. montanus), needs careful observation to distinguish it from the last-named, as, roughly speaking, it occupies the same localities both at home and abroad, though it is curiously local, while it extends to the Mediterranean, Siberia, China, Japan, and possibly northern Africa. The crown and nape are rich brown, the white check shews a black patch, and the wing two white bars, while in the cock Sparrow the crown is grey, there is no cheek patch, and the wing has only one bar. Moreover the sexes are alike in the Tree Sparrow, whereas everyone is familiar with the dowdy brown hen of the other species. In both the cocks have black throats. Again the large untidy nest of the House Sparrow is placed in spouts, gutters, holes in masonry, banks or trees, and also in hawthorns or the like in the open; that of the Tree Sparrow is invariably in a hole, whether 
it be in a wall, railway cutting, pollard willow or whatnot, and is built with much less straw and feathers, while the eggs are decidedly smaller and more delicate than those of its congener, and generally marked with deep brown instead of black and grey. In fact, just as the House Sparrow's eggs are rather like those of the Pied Wagtail, those of the Tree Sparrow are generally like those of the Meadow Pipit. The chirping and chattering notes of the two species are also easily distinguished by those well acquainted with them.

The Chaffinch (Fringilla coelebs) is resident with us, though its numbers are greatly augmented in autumn by flocks which come from the north, for the bird ranges over Europe from the Arctic Circle southward and also across west Siberia. It is too well known to need description, but in north Africa and the Atlantic Islands the allied species are most interesting and practically to be considered distinct. After the breeding season the males keep by themselves to a considerable extent till spring, and thus the Chaffinch gains the name of "colebs," or bachelor. It is only too tame and familiar in most places, and is very fond of scratching up and eating newly sown seeds of cabbage, turnip or radish; yet both cock and hen are general favourites, and their call-note of "spink-spink" is always pleasant to the ear. The song varies considerably, but is always of the same stamp; the nest of moss and wool, studded outside with lichens, is one of our prettiest pieces of bird-architecture; and the eggs, which are spotted with red-brown, have a curious dull greenish groundcolour, or are rarely quite blue.

The Brambling or Mountain-Finch ( $F$. montifringilla) arrives on our eastern coasts about October, and only 
remains with us till March, for supposed instances of its breeding in Britain are erroneous. Huge flocks often visit us, but are much rarer in the west and in Ireland; abroad it spends the summer in Subarctic Europe and Asia, where it builds a rougher nest than the Chaffinch on the trees or bushes that are available, and lays very similar eggs. It is extremely fond of beech-mast, and is therefore commonly met with in winter on the ground under beech trees, but it also eats seeds in general as well as insects. The summer habits are a little different from those of its congener, as might be imagined in a far northern climate, while the song, if it should so be called, is harsh and jarring. The black upper parts, and white for green rump distinguish the male from the cock Chaffinch. The female is chiefly brown above.

That well-known cage-bird the Linnet (Acanthis cannabina) is a resident in Britain in the usual sense of the word; that is, the flocks move southwards within the kingdom in winter and are joined by large numbers from the Continent. Abroad it ranges in its various forms over the Palæarctic region to Kashmir. Bird-catchers know it as the Grey, Brown, or Red Linnet, the reason for the various names being that breeding males have the brown plumage decorated with red on the forehead, crown, and breast, while hens and individuals not in perfect plumage exhibit no red, which is, moreover, generally lost in captivity. Restless at the nest, and shy at all times, Linnets are usually seen flocking to the stubbles to feed, flitting about gorse-covers, or passing overhead with a somewhat jerky flight as they utter reiterated twittering notes; in a cage the song seems to become more full and to consist partly of 
imitations. The food is of grain and seeds and partly of fruit. The nest of roots, lined with wool and hair, is placed in low hedges, bushes, or even in rough herbage; gorse-covers are favourite spots, and large colonies have been found in thickets of privet. The five or six eggs are greenish or bluish white with rufous spots, large specimens resembling those of the Greenfinch.

The Twite or Mountain-Linnet (A. flavirostris) is often mistaken for the Linnet proper, but is readily distinguished at close quarters by the very short beak and the rose-red rump of the male; it represents its congener on our higher hills and moorlands from Devon, central and northern England, to Scotland and Ireland, being specially abundant in the northern isles. The "Heather Lintie," as it is called in Scotland, only breeds abroad from Scandinavia to Finland, if we separate a paler Asiatic form. Its habits in general are those of the Linnet; but the nest is either in the heather or on some grassy slope, often near the sea, while the eggs are distinctly bluer and rounder than those of its congener.

The Redpolls, as a genus, have given a considerable amount of trouble to ornithologists, who estimate quite differently the value of the various forms-which are worthy of specific, which of subspecific rank. Apart from accidental occurrences, however, we are only here concerned with two of these, the Mealy Redpoll and the Lesser Redpoll, and they are sufficiently distinct. The Lesser Redpoll (A. cabaret) is best known in the cold season, when flocks, great or small, are seen feeding on the seeds of birches, alders, or conifers, that form the chief article of their diet; they generally fly high overhead, uttering their twittering cries, which resemble, 
but can readily be distinguished from, those of the Linnet. They change their feerling-grounds continually and are strong on the wing, yet they can hardly be called shy, and are fairly tame in the breeding season. The male of this smallest of our Finches is a pretty little brown bird with black throat, red crown and breast, and pinkish rump; the female has no red save on the head, and even this is lacking in the young. The nest, placed in a tall hedge, a shrub, or a low growth of poplar, alder, willow or hazel, is even prettier than the builder, being composed of grass, moss, and wool, thickly lined with willow or poplar down, where such is obtainable; the half-dozen eggs are of a darker greenish blue than in the Linnets, and have rufous blotches. This species nests locally from the Orkneys and Inner Hebrides to the south of England and Ireland, while abroad it is by some considered to range over western and central Europe. But here again the question of forms makes a definite statement dangerous. It certainly breeds in the Alps.

The Mealy Redpoll proper (A. linaria) migrates to our northern and north-eastern coasts from the far north after breeding; it is most common in hard winters, and is little seen south of Yorkshire, though when it does come it generally comes in flocks; in the west and in Ireland it is rare. It is a larger and much lighter bird than the last species, being streaked with white above ; in habits, however, it hardly differs, allowing for any changes due to a residence in the extreme north of Europe, Asia, and America; down is there less easy to procure for the nest, which is a little larger, as are the eggs.

The Bullfinch (Pyrrhula pyrrhula) is so well known 
in cages that it would hardly be necessary to call attention to its coloration, were it not that the conspicuous black head, grey back, white rump and red breast easily enable the male to be identified out of

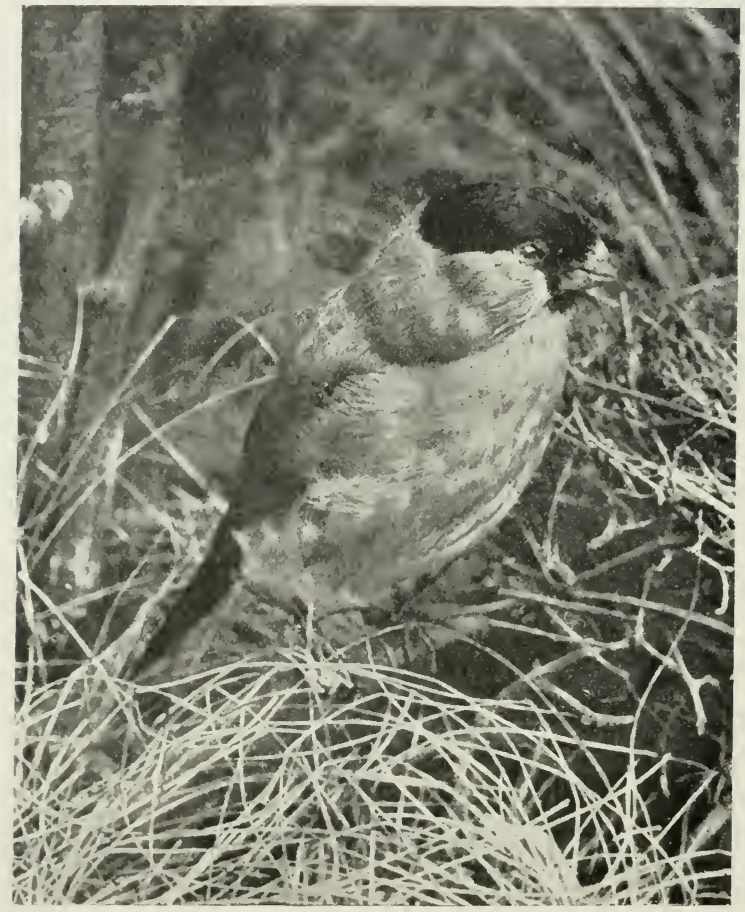

Bullfinch

doors. The female is browner above and vinous-brown below. It is a shy bird, a frequenter of woods and thickets in the breeding season, and more or less retiring at any time. South of the latitude of Skye it is generally common in suitable localities, though often overlooked; 
while many gardeners shoot it at sight for the damage it does in spring to the buds of fruit-trees, possibly in search of insects. These with their larva, seeds and berries constitute the food. 'The flight is rather heavy, the notes low and mournful, but they develop into a fine piping song in captivity, for the Bullfinch is an apt pupil when taught. 'The nest, built in a bush, creeper, or thicket, is made of roots lined with hair, and contains four or five bright greenish blue eggs with purple spots; it has invariably a foundation of dry twigs. If we separate the northern European and western Siberian bird from ours it will stand as $P$. pyrrhula proper, and the British as a subspecies pileata.

'The Crossbill (Loxia curvirostra) has been much in evidence since 1909, when larger flocks of the Continental race than usual appeared in June and July, and remained to breed in 1910 . They were not confined to any single district, but were most abundant in the conifer woods near Thetford in Norfolk-where some pairs are still nesting-in 1914. The local keepers assert that a few birds have always bred there, and exceptional instances for other counties had been on record for many years back; but the Crossbill used only to be known as a regular inhabitant with us of the fine oid Scoteh-fir woods of the shires from Aberdeen and Inverness northwards, where the local race is by some considered to differ from the Continental and is named Loxia curvirostra scotica. This species has now nested for a considerable number of years in Ireland. It builds a compact or sometimes careless strueture of twigs, grass and moss, not uncommonly decorated with lichens, and lays four or five eggs a little larger than, but similar to, those of the Greenfinch. Scotch-firs are 
preferred, but larches are also utilized, and the nest is more often on a horizontal branch than near the trunk of the tree. The male is very conspicuous when he sits in the morning on some tree-top, pouring forth his lively song and shewing off his crimson colours; only birds in perfect plumage, however, are so bright, the remainder being orange and the females greenish, while all have browner wings and tail. The young are much greyer. The Crossbill's presence is generally made evident by the number of fir-cones with their seeds extracted which lie below the trees, but insects of different sorts, eaterpillars and fruit give variety to the diet. As cones become scarce the flocks move to new places, and their low sibilant notes are heard no more; the flight is strong, as might be expected from the size of the bird. This species, in slightly varying forms, breeds in the conifer-districts of both the Palæaretic and the Nearctic regions, a specially stout-billed race having been denominated the Parrot Crossbill. The characteristic erossing of the tips of the mandibles is not peculiar to the Crossbills ; it has, for instance, occurred exceptionally in Redpolls.

Subfamily Emberizinæ, or Buntings

The Corn-Bunting (Emberiza calandra), a heavy plain brown bird with whitish under surface streaked with the same colour, is with us at all times of year, though a certain amount of migration is known to take place.

It breeds in various places throughout the Palæaretic region save in the far north and east, and is abundant, though local, in Britain. It prefers uncultivated districts and those without woods, not ascending to any great altitude, and being nowhere more common than in Orkney 
and shetland. Its heavy flight and droning note distinguish it from all our other Buntings, and it is always in evidenee during summer on its favourite perches, which are usually a bush-top or a telegraph-wire. After breeding, it is often seen in flocks, and lives almost entirely on grain. The nest of grass and hair is placed among coarse herbage or in young corn, and the large eggs, which are laid in May or later, have

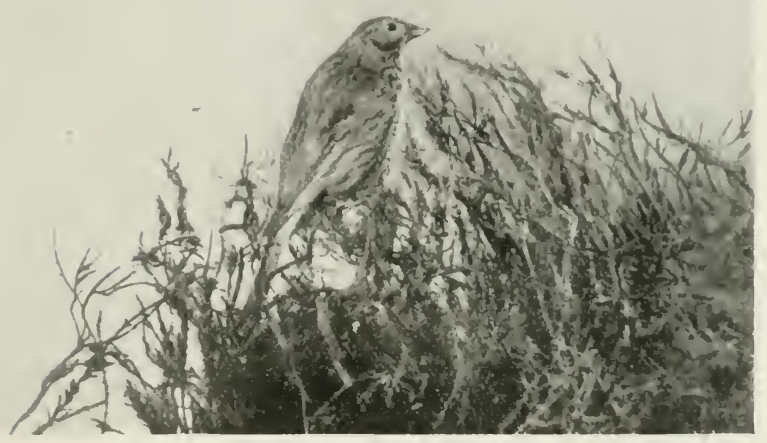

Corn-Bunting

a yellowish or purplish ground-colour, finely blotehed and streaked with browns and lilaes.

A brilliant yellow head, equally bright under parts, and a red-brown rump, hardly marred by brown streaks, are the well-known characteristies of the male Yellow Bunting or Yellowhammer (Emberiza citrinella), while the song of "a little bit of bread and no cheese" and the eggs beautifully spotted and serawled with purplish

E. $B$. 
or reddish brown are familiar to us all. In most other respects it resembles the Corn-Bunting, that is in flight, food, choice of perch, nest, and sociability. It breeds, however, several times in a season and often builds its nest in young trees or bushes. Northwards it is much less common than its congener and abroad hardly extends southwards beyond the Pyrenees and the Alps. The female is much browner.

The rarer and more retiring Cirl Bunting (Emberiza cirlus) of central and southern Europe and north-west Africa is also a resident in southern England, but has not been proved to breed north of Yorkshire and rarely does so in north Wales. It may almost be called abundant, however, in parts of Hampshire and Devonshire. If a clear view is obtained, the male is easily distinguishable from the Yellowhammer by its black throat, lores and ear-coverts, and much less yellow head and lower parts. The female is almost brown above with a buff instead of a black throat. The song is like the first part of that of the Yellowhammer, but has not the concluding phrase; the flight and nest are similar, but the eggs have a somewhat blue groundcolour and more spots than scrawls. The site chosen is usually in some dry sunny locality near houses, especially on chalk downs or west-country "combes," and the actual place most commonly a low bush.

It is rather unfortunate that we have been obliged to transfer the popular name of Black-headed Bunting from Emberiza schœniclus to a foreign species, nor does the decision seem absolutely necessary ; but it is useless now to complain, and fortunately we have a good alternative in "Reed Bunting." The black head and breast, white collar and belly, and mainly red-brown 
upper parts make the male a very conspieuous object as he sits on the top of some bush or clings to the highest reeds, whence he flits along before an intruder to another similar spot. He is by no means shy and constantly utters a sharp call-note, besides which he has a clear drawling song of the type usual in Buntings. The hen is brown with reddish head and black streaks on the throat. In winter the birds sometimes gather in flocks, but generally frequent the fields and especially the ditches ; for there seems to be little migration to or from the Continent in the case of our home-bred birds, though occasionally numbers cross to us from abroad. There the range extends over all the Palæarctic region, except north Africa, if we do not separate smaller or much larger billed forms ; in Britain this species has not been found breeding in Shetland. The food includes insects from the marshes, small crustaceans and mollusks, grain and seeds of various plants. The nest, of grass and moss or dead marshherbage, is placed in a low shrub, or in vegetation just clear of the ground, but always in damp spots; it is lined with hair or dry reed-flowers and contains about five brownish white or distinctly green eggs with purplish brown markings, which may include a few scrawls.

The Lapland Bunting (Calcarius lapponicus) was, if not overlooked, a decidedly rare winter migrant to Britain until 1892, when a large irruption took place, followed by others in each subsequent year. Its habits are more those of a Pipit than a Bunting, and with us it generally keeps to the shores and coast-lands. The black crown and face of the male are in striking eontrast with the chestnut nape and white sides of the 
neck; otherwise the bird is chiefly brown, while the female is much plainer brown. As its breeding haunts, though circumpolar, are in the Arctic and Subarctic countries, the eggs were for long rare in collections; they are richly spotted with brown and are laid in a grassy nest warmly lined with feathers, which is placed on a dry spot in a marsh-commonly to the north of the tree limit-in a willow swamp or similar place. The song is said to resemble that of the Linnet.

The Snow Bunting (Plectrophenax nivalis), also an inhabitant of the more Arctic regions of both worlds, as well as Iceland and the Færoes, is of particular interest to British ornithologists, for not only do large numbers visit us between October and April, but a good many pairs are now known to breed at the tops of the loftiest Scottish mountains. There the nest, of such substances as can be procured, is placed deep among the boulders of the "screes," but in the north of Europe it is often more exposed and almost at sea level. The five roundish white eggs are prettily marked with rustcolour, brown and lilac. The song is more melodious than in Buntings generally; the flight is strong; the food consists of insects in summer, while in winter the birds frequent our sea-side dunes, fields, and stackyards for the seeds and grain to be found there. The cock is a beautiful white bird with black on the mantle, tail and wings, which becomes chestnut in autumn; he is whiter again in winter, but the hen and the young. are always much duller, the former being greyer with blackish head. 
Family STURNIDÆ, or Starlings

It is difficult to believe that the Starling (Sturnus vulgaris), which is now so abundant from shetland to

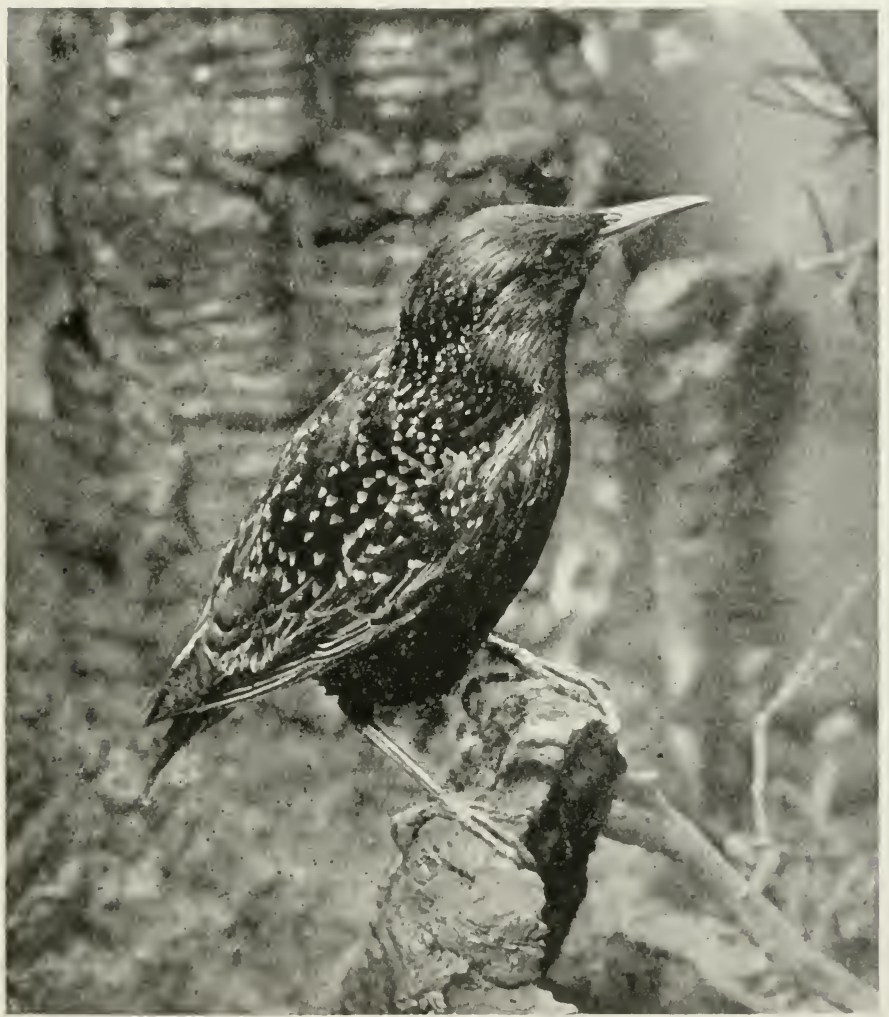

\section{Starling}

Cornwall, was hardly known north of the Scottish Border at the beginning of last century. The increase of late years has been enormous, and it is now no 
uncommon thing to discover a winter " roost " of many thousands, which literally break down reeds, shrubs or even small trees by their combined weight. Abroad our bird is sufficiently common throughout most of Europe except the far north, Spain, Portugal, Sardinia, Corsica, Sicily, and the Færoes; in Asia a form occurs in Siberia and from Asia Minor to north India. The question of its range is complicated by the occurrence of an unspotted species in south Europe. The buff markings on the black plumage with its green and purple sheen are only characteristic of the adult Starling, for the young are plain brown with duller yellow bill. In this state they are often seen in autumn flocking to our shores, where migrants also arrive from abroad; but the birds are more familiar to us on our houses and in our woods, where they make a very untidy straw nest in almost any sort of hole and lay some six pale blue eggs. Occasionally heaps of stones on roadsides are made use of. Starlings are decidedly beneficial to the farmer, as they eat huge quantities of slugs, worms, insects and their larvæ; the only harm they do is to ornamental berries or fruit, if we except the few small birds they are occasionally known to kill. Wary but by no means shy, their funny ways and queer little hurried runs when feeding on the ground are known to every observer, but the varied shrill notes of these admirable mimics often delude him as to their author. The flight is strong, but somewhat spasmodic. Our breeding stock is partially migratory.

The Rose-coloured Starling (Pastor roseus) with its beautiful rose-pink body, black wings, tail, neck, and crested head, is an irregular visitor to Britain, generally between spring and autumn, when it attaches itself to 
companies of Starlings. It is a south-eastern European and west Asiatic species, occasionally flocking to Italy and Hungary, which breeds in large colonies, that constantly change their quarters, perhaps according to the food-supply. A farourite article of diet is the migratory locust, but other insects, berries, fruit and grain are also eaten. The nests of grass and feathers are placed in holes in old ruins, cliffs, and banks; the eggs are bluish white. It is a comparatively shy bird, with the general habits of a Starling, and a harsh chattering cry.

\section{Family CORVIDAF, or the Crow Tribe}

The glossy black Chough (Pyrrhocorax pyrrhocorax), with its brilliant red bill and legs, was evidently a much commoner bird in Britain of old than at the present day, when it barely holds its own on the cliffs of the west and in Ireland. On the east the last nest appears to have been recorded about the middle of the nineteenth century, at St Abb's Head in Berwickshire. It rarely breeds inland in our country, but it does so in many parts of the high mountains of western and southern Europe, Asia, Abyssinia and north-west Africa. It also inhabits the islands of the Mediterranean, the Canaries and the coasts of west Europe, with the exception of Scandinavia. This shy bird is non-migratory and may therefore be seen at any season actively hunting for food on the ground, after the manner of the Starling, but it has no special faney for fruits. Occasionally it utters notes resembling "chough-chough," but the usual ery is elear and ringing; the flight may be prolonged, but generally consists of eireling movements varied by tumbling. The nest, placed in some hole in a steep slope, a cave or cliff-face, and often most 
difficult of access, is made of twigs, heather and the like, with wool and hair for lining; the four or five

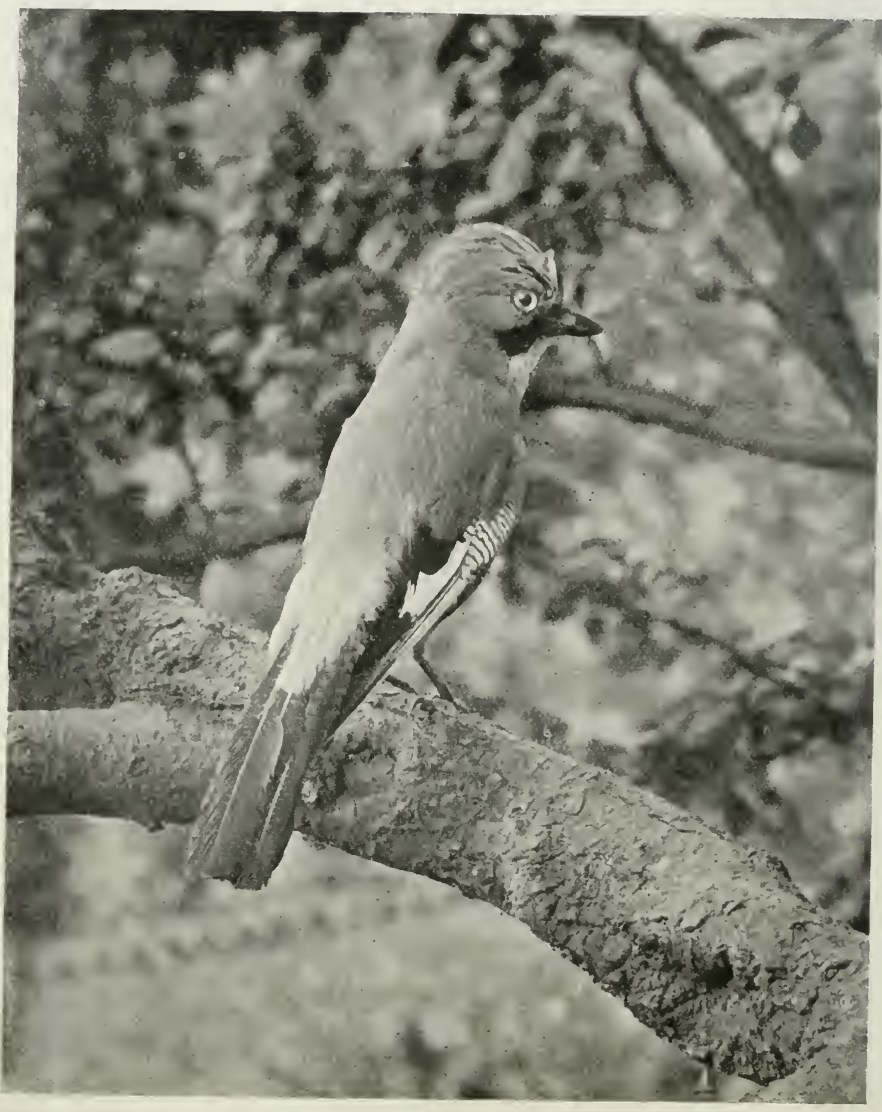

\section{Jay}

eggs are yellowish or greenish white with markings of grey, brown, and lilac. 
A wary and subtle bird is the Jay (Garmulus glan(arius), as much admired for its beauty as hated by gamekeepers for its destructive tendencies. Fawncolour, black and white are mingled in its plumage in due proportion, while a large erest and a mottled blue wing-patch enhance its attractiveness. The foor consists of worms and insects, acorns, nuts, and other fruits, and unfortunately also of the eggs and young of birds; the flight is heavy and the reiterated notes harsh and screaming. The nest, sometimes built in the fork of a tree, but ordinarily in thick bushy copsewood, is of twigs, grass and roots, while the four or five greenish eggs are closely freckled with olive and occasionally exhibit a black scrawl. Owing to persecution the Jay is local with us and to the northward only reaches Inverness-shire; the typical form, moreover, is now held to differ from the British, which is again a close ally of other European, Asiatic, and north African species.

Not many years ago the pretty long-tailed black and white Magpie (Pica pica) was often seen in most of our counties, and was well known for its cumning ways and jarring notes. Now, however, the balance of nature has been so much disturbed by game-preservers that the bird is becoming rare, except where the preservation is incomplete. No doubt its fate is more or less merited, as it is destructive to young birds and eggs, but it used to be a great feature in the landscape, being continually seen moving with strong but low flight from one shelter to another, or in spring busy round its wonderful nest. This is a great roundish mass of sticks lined with clay and then with roots, while the top or roof is comparatively thin and flat, 
and access is gained at the side. The eggs, generally more than six in number, are greenish white with olive and brown markings. If we ignore various forms that have been described, the Magpie ranges over Europe, north Asia, north Africa and even western North America, but there are fairly recognisable subspecies.

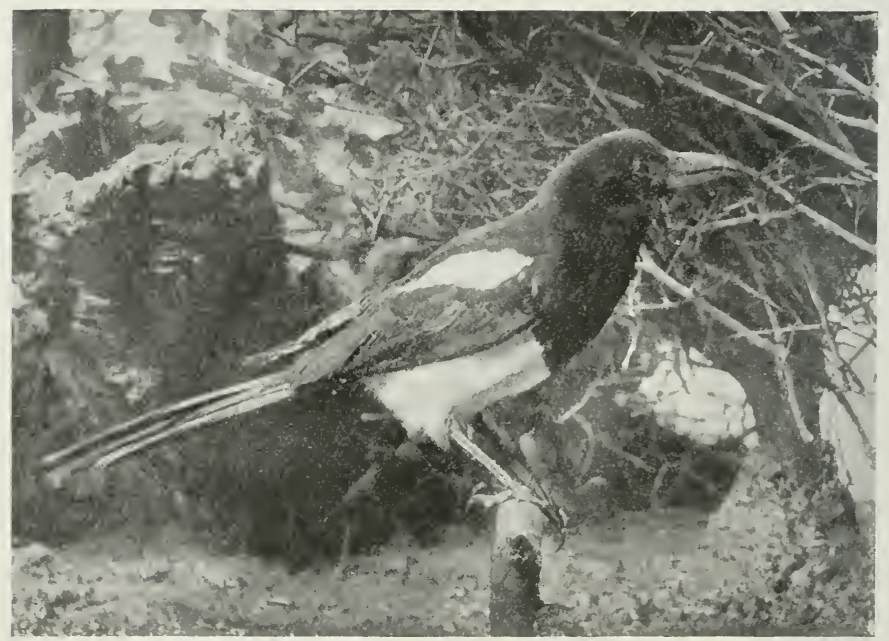

Magpie

The genus Corvus, or Crow, includes not only the Crows proper, but also the Jackdaw and the Raven, all of which are big glossy black birds. The Jackdaw (C. monedula) breeds throughout the Palæarctic region as far eastward as the Yenisei river, with the exception of the more Arctic parts of Europe, the Færoes and Iceland; it is easily distinguished by its grey nape, while its note is not a caw, but a repetition of "jake, 
jake." The curious tumbling flight, the gregarious habits, and the thievish propensities are matters of common knowledge; the food consists of insects, worms, sheeps' parasites, and so forth, and also of any eggs the bird can procure. Single pairs often choose hollow trees or chimneys for their big stick and wool

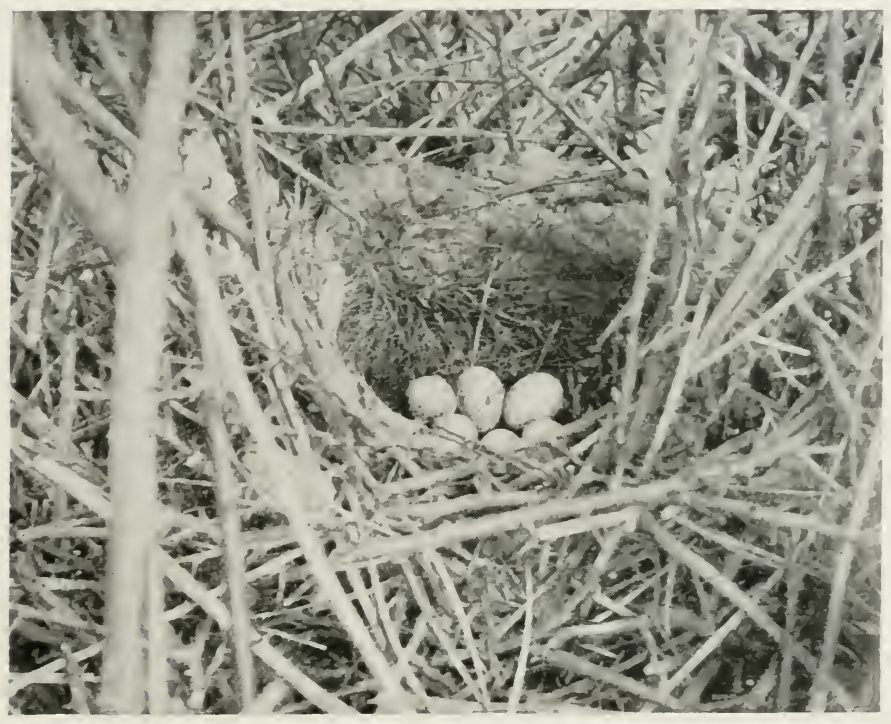

Magpie's nest

nest, but colonies are very common and build in holes in eliffs, ruins, chureh towers, and other like places, as well as in rabbit-holes on the hills. Some half-dozen green or more rarely bluish eggs are laid, with black, brown, and olive blotehes or spots.

The Raven $(C$. corax) is now a rare bird in most places, though formerly it commonly bred inland in 
big trees; such sites for the nest are practically a matter of ancient history in our southern counties, those now chosen being on hill-side crags or sea-side cliffs, and usually in spots very difficult of access on

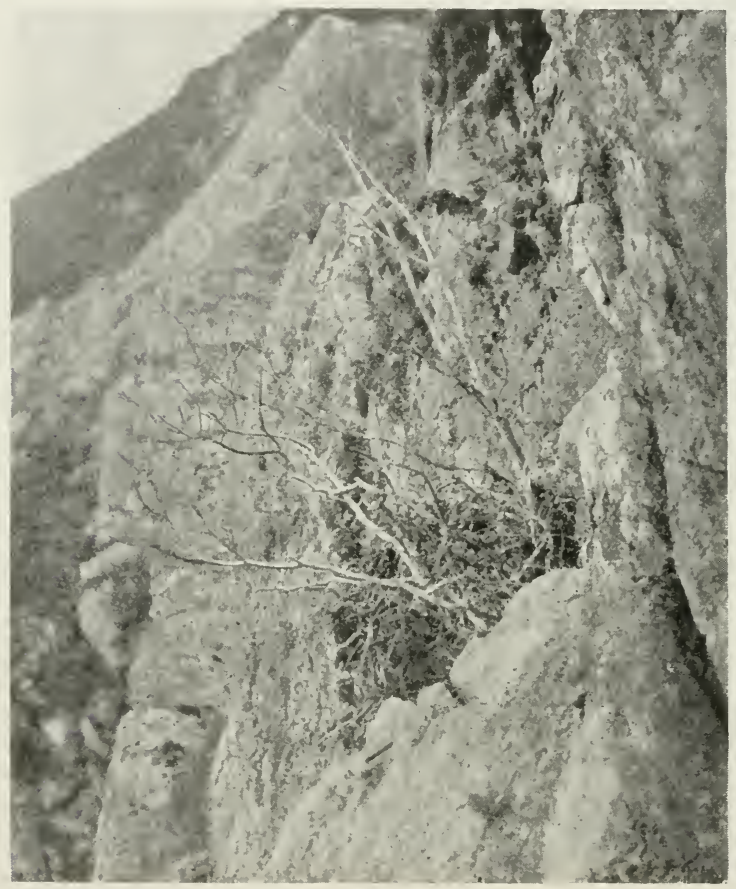

Raven's nest

account of overhanging rock-faces. A great mass of sticks lined with softer materials is collected in some larger hole or vertical fissure, and on these are deposited about five green eggs with olive and brown markings distributed over the shell: most exceptionally the 
coloration is red. They are laid very early in the north, but often later from the Border country to south-west England. This fine glossy black bird is still fairly abundant in northern Siotland, on the Welsh coast and in Ireland; abroad it breeds throughout Europe, northern Asia and North America, but other species or races take its place in Africa. 'The flight is powerful but slow, and both sexes tumble in the air, generally in the neighbourhood of the nest; the note is a harsh barking sound, the food is of all descriptions, including weakly lambs, small mammals, birds, eggs, and carrion.

The Carrion Crow ( $C$. corone) and the Grey or Hooded Crow $(C$. cornix) may be considered together, for the latter is little more than a grey-backed and grey-breasted race of the former, which interbreeds with it where their ranges overlap. Many migrants arrive in autumn, and do not all leave us in winter. In Britain the black bird reaches from the south to about midScotland, but the particoloured bird is almost confined in the breeding season to the north of the Firth of Forth, the Isle of Man, and Ireland, while it also has a more northerly and south-easterly range in Europe. This, however, must be taken as a very rough statement, as a great amount of overlapping takes place. and both forms extend to northern Asia, while even in Britain nests may be found down to the Scottish borders. Rooks are often called Crows, but the true Crows have a decidedly harsher voice and are, if anything, more difficult to approach; they are notorious egg-stealers and destroy much young game, but they feed also on other small birds and mammals, on carrion, insects, and fish, when they can catch it. They are 
therefore a public nuisance and not beneficial, as Rooks are. From autumn to spring numbers are seen in the open country or on the shore, but in spring our native stocks retire to the woodlands or the hill-country, where they build on a tree or rock a large nest of sticks, lined with wool and other soft materials. The four or five eggs resemble those of the Raven, but are smaller. On the sea-coast the nest is often in a cliff. Colonies are not formed. The flight is similar to that of the next species.

The Rook ( $C$. frugilegus), on the other hand, breeds in colonies often of hundreds of birds, the larger rookeries being also used as winter resorts. The nests are usually on lofty trees, but in quiet places may be much nearer the ground and exceptionally on it ; they are built of sticks and mainly lined with straw, while the eggs are "small editions" of those of their congeners. In the rookeries a vast amount of cawing is always going on, and the birds are tame enough, but at other times they are very wary, and constantly post sentinels when feeding in the fields. The amount of insect pests that is consumed must be incalculable, and the Rook is doubtless of the greatest utility, but in certain places it takes to bad habits and imitates the Crow in the destruction of eggs of game. This simply points to the fact that the natural food-supply will only maintain a certain number of individuals, and that any excess should be checked by shooting the young. This species is found breeding throughout Britain as far north as the Orkneys; it does not do so in southern Europe, but ranges over the northern portion and to Siberia. An adult Rook is characterized by a broad tract of white warty skin round the base of the bill, but the 
young have that part feathered. and are best distinguished from Crows by the rlark or livid, as opposed to pale flesh-coloured. inside of the mouth. These

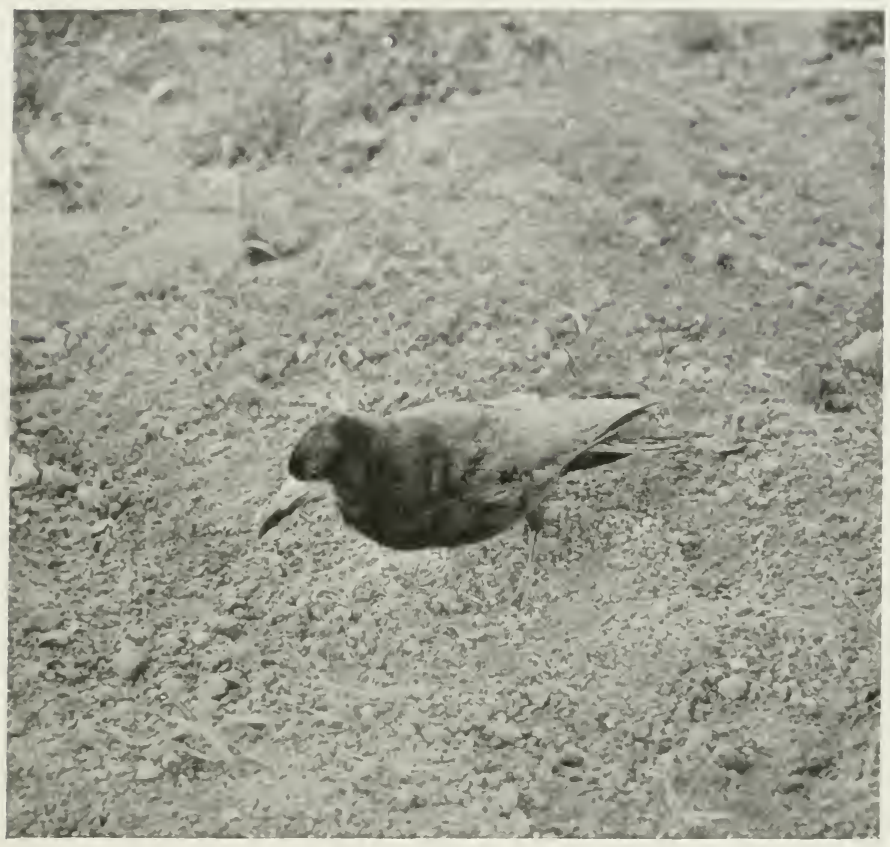

\section{Rook}

birds are constant migrants to and from the Continent. The flight is powerful, if slightly laboured.

\section{Family ALAUDID出, or Larks}

The Skylark (Alauda arvensis) is too well known to need any description, but it must be noted that its erectile crest has sometimes caused it to be taken by 
the uninitiated for the very different Crested Lark. Whether it be seen rising from the ground and flying low before us, diligently dusting itself on the roads, or soaring high in the air, it is always the same familiar friend, while its joyous song, uttered on the wing at all times of year, is one of the most delightful sounds of the country-side. The notes are no doubt most

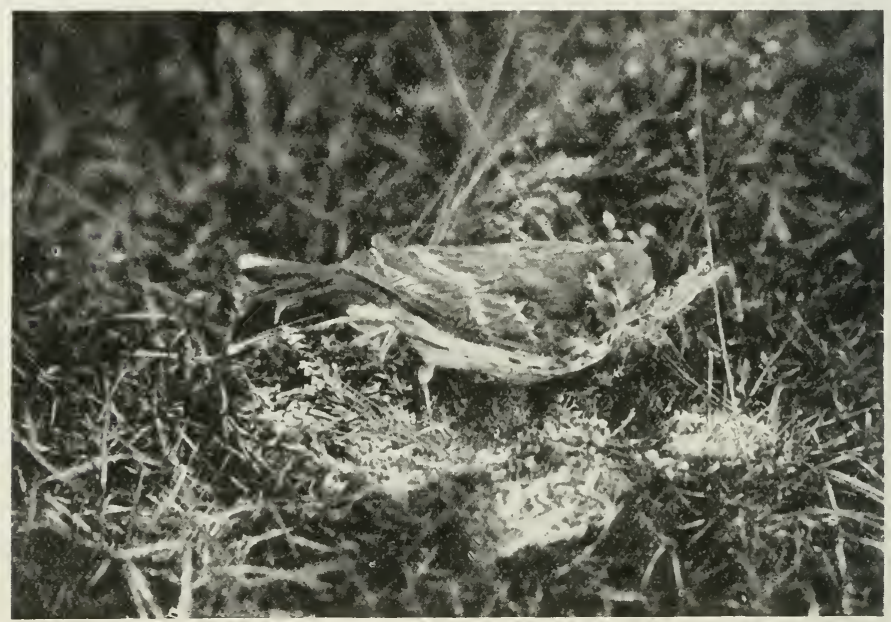

Skylark

perfect in the breeding season, when the male rises as far as the keenest sight can follow him and serenades his sitting mate, but they may generally be heard in sunny weather even in winter. The food consists chiefly of insects and worms, with a certain proportion of seeds; the nest is made of grasses, and is built in pastures, young corn fields, or rough herbage, or even on banks and sandy flats, and generally contains four 
or five eggs of a whitish ground-colour thickly rlotted with brown and grey. The Skylark is a great migrant and is constantly seen passing backwards and forwards to the Continent on passage, while it breeds throughout the Palaaretic region (in several forms), and even beyond the Arctie Cirele northwards.

The Wood-lark (Lullula arborea) is easily distinguished from the Skylark by its smaller size, short tail and much broader buff streak over the eye, or at a distance by its lighter appearance and somewhat Chat-like movements. It does not frequent the interior of woods, but is to be found on dry sunny fields or banks on their outskirts, heaths and sandy places, where it makes its nest in rather bare spots and lays four or five eggs, generally with brighter markings than those of its congener. 'They are small and vary considerably in colour. The sweet song of reiterated notes is uttered while the bird is hovering at a moderate height in the air, or while sitting on the outer branch of a tree; it is very noticeable in autumn, as well as spring, and would be more generally admired were the songster not so local, for it is never abundant, though found in small colonies in England, ehiefly in the eastern and southern districts, in Wales, and Wicklow in Ireland. In Europe and north-west Afriea this species breeds in the temperate regions, as it does in Persia and Transcaspia, but it is equally local or but little commoner than with us, while it hardly changes its quarters in Britain during the year. In Scotland the Tree-pipit is often termed "Wood-lark," but the former bird does not arrive till the latter has begun to breed, while the habits, nest and eggs are quite unmistakeable. The food is similar to that of the Skylark. 





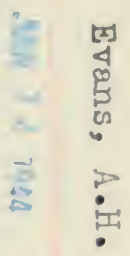


